XXXII.-On the Chemical Constitution and Nature of Organic Radicals.

By H. Kolbe., Рн. D., F.C.S.

Do compound radicals exist in organic combinations, exercising therein the functions of simple elements, and combining, like the latter, with oxygen, sulphur, chlorine, \&c., in certain atomic proportions, to form oxides (acids), sulphides and chlorides?

Do these compound radicals consist of unalterable groups of atoms, or can the substitution of their hydrogen by chlorine, bromine, hyponitric acid, \&c., be effected, unaccompanied by the disturbance of chemical equilibrium? 
Is it at variance with the principles of the electro-chemical theory, that elements of such different chemical properties, as hydrogen and chlorine, should displace each other; and that oxygen, chlorine, and similar bodies of decidedly electro-negative character, should rank among the constituents of organic radicals?

The above questions, first set on foot by the discovery of chloracetic acid, have been answered in various ways, and most decidedly and minutely by Berzelius, in the correspondence that lasted for some years between himself and Dumas. These interesting discussions were unfortunately interrupted by the death of the first-named chemist, without any understanding or approximation of views being effected, so that the opinions of chemists are, to this day, widely at variance with regard to the above points. Berzelius, and with him the greater number of German chemists, have, as is well known, adhered to their opinion of the existence of compound radicals, the correctness of which they have considered as proved by the successful isolation and the chemical properties of cyanogen and cacodyl. In addition to this, Berzelius obstinately defended the principle against all attacks made by adherents to the theory of substitution, that organic radicals were unalterable groups of atoms; that substitution could not be effected in them without a thorough alteration of their chemical constitution, least of all the substitution of hydrogen by bodies of such prominently electro-negative properties as chlorine, bromine, oxygen, \&c.; and that the assumption of organic radicals containing oxygen or chlorine, was in contradiction to the principles of the electro-chemical theory.

On the other hand, Dumas, without distinctly stating whether, indeed, he assumes the existence of organic radicals, has maintained the principle that compounds, containing an equal number of equivalents arranged in a like manner, are possessed of the same fundamental properties, and that the function exercised by an element in organic combination is not dependent upon its original properties, but rather upon the position which it occupies in the compound. Both chemists agree in the opinion, that the assumption of a replacement of the positive hydrogen by the negative chlorine in a compound radical, is at variance with the electro-chemical theory, because, according to this theory, the nature of a compound cannot be considered as independent of the chemical nature of its constituents. This accordance of opinion, with respect to the latter point, has been most probably the principal reason why the question as to the immutability of organic radicals has not been made the subject of investigation to the degree that it merits. 
It may be considered as beyond all doubt that the theory of radicals in its present state no longer suffices to furnish proper explanations of the innumerable metamorphoses resulting from so-called substitution, and that, by a continued adherence to the unchangeability of compound radicals, the secure foundation resulting from the theory of radicals becomes continually weakened. We are, indeed, at the present moment, almost forced by facts to assume that organic radicals are alterable groups of atoms, in which chlorine, bromine, hyponitric acid, \&c., may enter in the place of hydrogen, the molecular grouping of their atoms remaining unchanged, and secondary radicals being thus produced, which are possessed, in part, of properties similar to those of the primary ones. Instead of at once discussing the question, whether and how far this mode of viewing may be made to accord with the electro-chemical theory, I will endeavour, in the following pages, to apply this hypothesis to a series of organic combinations, and more particularly to those, the comportment and metamorphoses of which it has been most difficult to explain by the theory of radicals as it now stands.

The difficulty of bringing the behaviour of acetic acid with chlorine, and its reproduction from chloracetic acid, to accord with the assumption of an unalterable acetyl-radical of the formula $\mathrm{C}_{4} \mathrm{H}_{3}$, first led Berzelius to construct the hypothesis, that acetic acid and chloracetic acid might be conjugated oxalic acids, the one containing methyl, and the other sesquichloride of carbon as adjuncts, and that the conversion of acetic into chloracetic acid was solely due to a metamorphosis of the adjunct, while the oxalic acid itself remained unaltered.

Whatever may be the opinion entertained as to the value of this hypothesis, it cannot be denied that the pre-existence of methyl in acetic acid has received a high degree of probability from facts, most of which were only subsequently discovered. Independent of the analogy existing between acetic and chloracetic acid on the one hand, and between methylo-hyposulphuric acid and sesqui-chlorocarbohyposulphuric acid on the other, to which $I$ have already referred in a previous paper,* the conversion of acetate of ammonia into cyanide of methyl, and the reproduction of acetic acid from the latter, as also the decomposition of acetic acid, by the galvanic current, into methyl and carbonic acid, can scarcely be satisfactorily interpreted, otherwise than by the assumption of the existence of methyl as a component part of acetic acid.

* Ann. Ch. Pharm. d. LIV, 148, ff ; Chem. Soc. Mem. II, 360. 
It has not as yet been attempted to extend the above hypothesis to the remaining combinations of acetyl, which, if acetic acid were methyloxalic acid, must evidently have a composition corresponding to this view. The result of such an attempt would be the necessity of assuming the existence in aldehyde, acetylous acid, chloride of acetyl, \&c., of the partly hypothetical bodies $\mathrm{C}_{2} \mathrm{O}, \mathrm{C}_{2} \mathrm{O}_{2}$ and $\mathrm{C}_{2} \mathrm{Cl}_{3}$ coupled with methyl. We should likewise be forced to assume that, in - the terchloride of acetyl (the so-called dichlorinated chloride of ethyl), which, according to Regnault, may be converted, by continuous boiling with alcoholic potassa, into acetic acid and chloride of potassium, the sesquichloride of carbon, considered as combined therein with methyl, must differ considerably in its properties from the same substance when uncombined, as the latter cannot be converted, by similar treatment, into the corresponding oxygen-compound, oxalic acid; moreover a further extension of the hypothesis to the remaining compounds allied to acetic acid-for example, to the other members of the series $\left(\mathrm{C}_{2} \mathrm{H}_{2}\right)_{\mathrm{n}} \mathrm{O}_{4}$, as also to benzoic acid and its homologues, \&c., would show that, instead of viewing them as oxides of compound radicals, as hitherto, we must consider them all as conjugate oxalic acids, and finally that, of all the radicals which are partly really isolated, there would be few or none remaining. Even cacodylic acid, if the replacement of a portion of its hydrogen by chlorine be accomplished, as there is little doubt it will, must no longer be considered as an oxygen-compound of cacodyl, but perhaps as arsenious acid conjugated with two equivalents of methyl.

If, however, we adhere less strictly to the immutability of organic radicals, another hypothesis, very nearly allied to the former, of the chemical constitution of acetic acid, and the acetyl-compounds in general, presents itself, possessing the advantages of the former, without sharing its defects, namely: that an acetyl-radical really exists in the acetyl-compounds; that it must not, however, be considered as a group of four equivalents of carbon and three equivalents of hydrogen, the four carbon equivalents of which possess equal functions, but that it should rather be viewed as a compound of two equivalents of carbon, and methyl as the adjunct:

$$
\text { Acetyl }=\left(\mathrm{C}_{2} \mathrm{H}_{3}\right)^{-} \mathrm{C}_{2} \text {, }
$$

in which the $\mathrm{C}_{2}$ presents the exclusive point of action for the powers of affinity of oxygen, chlorine, \&c.

According to this view, the composition of the acetyl-compounds, with which we are as yet acquainted, would be expressed by the following rational formulæ: 


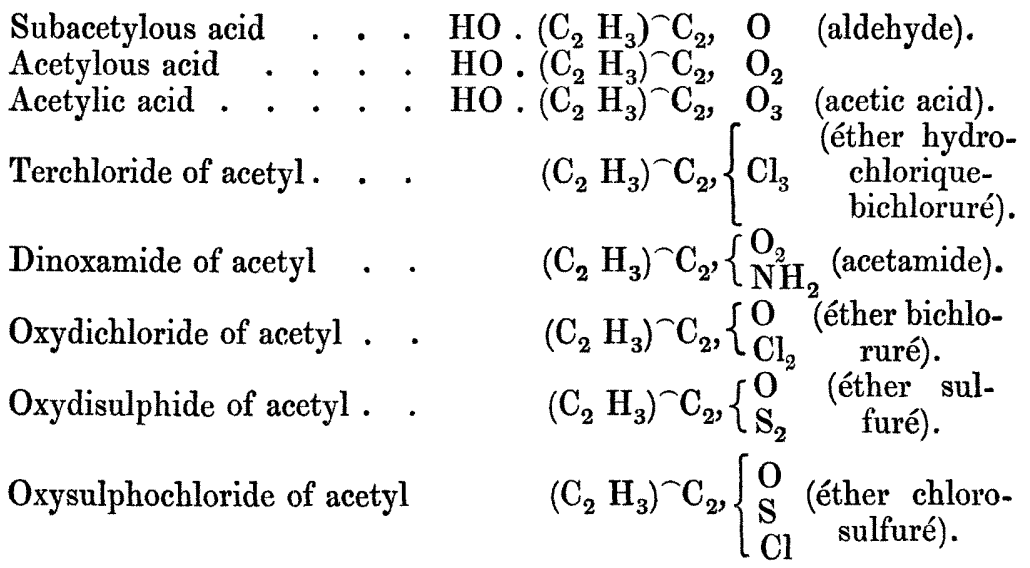

The assumption of this conjugate acetyl-radical in aldehyde and acetic acid, renders it evidently necessary that the interpretation hitherto given to the process of acetification should be slightly modified. The action of the oxygen on the alcohol effects probably, at first, the splitting of ethyl into methyl and the carbo-hydrogen $\mathrm{C}_{2} \mathrm{H}_{2}$, the elimination of which from organic compounds belongs to the most common phenomena. At the moment of its liberation it undergoes a further decomposition; as the hydrogen becomes oxidised, the two equivalents of carbon immediately reunite with the methyl, forming the conjugate acetyl-radical $\left(\mathrm{C}_{2} \mathrm{H}_{3}\right)-\mathrm{C}_{2}$, with which the oxygen of the oxide of ethyl remains combined :

$$
(\underbrace{\left.\mathrm{C}_{4} \mathrm{H}_{5}\right) \mathrm{O} . \mathrm{HO}}_{\text {Alcohol. }}+2 \mathrm{O}=\underbrace{\mathrm{HO},\left(\mathrm{C}_{2} \mathrm{H}_{5}\right)-\mathrm{C}_{2}, \mathrm{O}}_{\text {Aldehyde. }}+2 \mathrm{HO}
$$

The conversion of aldehyde into acetic acid by the direct assimilation of two equivalents of oxygen,

$$
\underbrace{\mathrm{HO} \cdot\left(\mathrm{C}_{2} \mathrm{H}_{3}\right)-\mathrm{C}_{2}}_{\text {Aldehyde. }}, \mathrm{O}+2 \mathrm{O}=\underbrace{\mathrm{HO} \cdot\left(\mathrm{C}_{2} \mathrm{H}_{3}\right) \mathrm{C}_{2}, \mathrm{O}_{3}}_{\text {Acetic acid. }}
$$

must be considered, as of old, as a pure process of oxidation.

It appears to me that all other relations of acetic acid to different compounds may be explained in an equally satisfactory manner by assuming it to be composed according to the above rational formula. Its formation from cyanide of methyl by boiling with potassa :

$$
(\underbrace{\left.\mathrm{C}_{2} \mathrm{H}_{3}\right), \mathrm{C}_{2} \mathrm{~N}}_{\text {Cyanide of methyl. }}+\mathrm{KO}+3 \mathrm{HO}=\underbrace{\mathrm{KO} \cdot\left(\mathrm{C}_{2} \mathrm{H}_{3}\right)-\mathrm{C}_{2}}_{\text {Acetate of potassa. }}, \mathrm{O}_{3}+\mathrm{N} \mathrm{H_{3 }}
$$


the decomposition of acetate of ammonia, by distillation with phosphoric acid, into cyanide of methyl and water:

$$
\underbrace{\mathrm{NH}_{4} \mathrm{O} \cdot\left(\mathrm{C}_{2} \mathrm{H}_{3}\right) \mathrm{C}_{2},}_{\text {Acetate of ammonia. }}, \mathrm{O}_{3}+\mathrm{n} \mathrm{PO}_{5}=\underbrace{\left(\mathrm{C}_{2} \mathrm{H}_{3}\right) \mathrm{C}_{2}}_{\text {Cyanide of methyl. }} \mathrm{N}+4 \mathrm{HO}+\mathrm{n} \mathrm{PO}_{5}
$$

the decomposition of an aqueous solution of acetate of potassa, at the oxygen-pole of the galvanic current, into methyl and carbonic acid:

$$
\underbrace{\mathrm{KO} \cdot\left(\mathrm{C}_{2} \mathrm{H}_{3}\right)-\mathrm{C}_{2}, \mathrm{O}_{3}}_{\text {Acetate of potassa. }}+\mathrm{O}=\underbrace{\mathrm{C}_{2} \mathrm{H}_{3}}_{\text {Methyl. }}+\mathrm{KO}, \mathrm{CO}_{2}+\mathrm{CO}_{2}
$$

the conversion of acetic acid, by heating its lime-salt with hydrate of lime into carbonic acid and marsh-gas (hydride of methyl) :

$$
\underbrace{\mathrm{CaO} .\left(\mathrm{C}_{2} \mathrm{H}_{3}\right)-\mathrm{C}_{2}, \mathrm{O}_{3}}_{\text {Acetate of lime. }}+\mathrm{HO} \cdot \mathrm{CaO}=\underbrace{\mathrm{H}\left(\mathrm{C}_{2} \mathrm{H}_{3}\right.}_{\text {Marsh-gas. }})+2\left(\mathrm{CaO} . \mathrm{CO}_{2}\right)
$$

and finally, the formation of oxide of cacodyl, by the distillation of acetate of potassa with arsenious acid:

$2 \underbrace{\left[\mathrm{KO} .\left(\mathrm{C}_{2} \mathrm{H}_{3}\right)-\mathrm{C}_{2}\right.}_{\text {Acetate of potassa. }}, \mathrm{O}_{3}]+\mathrm{As} \mathrm{O}_{3}=\underbrace{\left(\mathrm{C}_{2} \mathrm{H}_{3}\right) 2 \mathrm{As}, \mathrm{O}}_{\text {Oxide of eacodyl. }}+2\left(\mathrm{KO}, \mathrm{CO}_{2}\right)+2 \mathrm{CO}_{2}$

All these decompositions are most simply and naturally expressed by the above equations. I consider it at present impossible to explain the formation of acetone from acetic acid, as we are as yet quite in the dark with regard to its rational composition, and, indeed, have not even established its empirical formula with certainty.

The opinion, defended with so much warmth by the adherents to the theory of substitution, that the so-called dichlorinated oxide of ethyl still possessed the constitution of oxide of ethyl, does now scarcely need any refutation. Not only do the close relations borne by this compound to acetic acid, into which it is converted by lengthened contact with water, almost preclude a doubt of its belonging to the acetyl-series, but it is of itself more than probable that the oxide of ethyl would undergo a similar metamorphosis by the action of chlorine as with oxygen. The action of chlorine on oxide of ethyl likewise appears to consist, in the first instance, of a splitting of the ethyl-group into methyl and $\mathrm{C}_{2} \mathrm{H}_{2}$, which is followed by the immediate decomposition of the latter carbo-hydrogen, and the formation of $\left(\mathrm{C}_{2} \mathrm{H}_{3}\right)^{-} \mathrm{C}_{2}$, together with hydrochloric acid; this radical, remaining in combination with the oxygen of the oxide of ethyl, assi- 
milates, in addition, two equivalents of free chlorine, and thus becomes $\left(\mathrm{C}_{2} \mathrm{H}_{3}\right)-\mathrm{C}_{2},\left\{\begin{array}{l}\mathrm{O} \\ \mathrm{Cl}_{2}\end{array}\right.$, i.e., oxydichloride of acetyl, according to the following equation :

$$
\underbrace{\mathrm{C}_{4} \mathrm{H}_{5} \mathrm{O}}_{\text {Oxide of ethyl. }}+4 \mathrm{Cl}=(\underbrace{\mathrm{C}_{2} \mathrm{H}_{3}}_{\text {Oxydichloride of acetyl. }})^{-\mathrm{C}_{2}},\left\{\begin{array}{l}
\mathrm{O} \\
\mathrm{Cl}_{2}
\end{array}+2 \mathrm{HCl}\right.
$$

The same mode of viewing may be applied with facility to the decomposition of this acetyl-compound by water or alkalis, into acetic and hydrochloric acids :

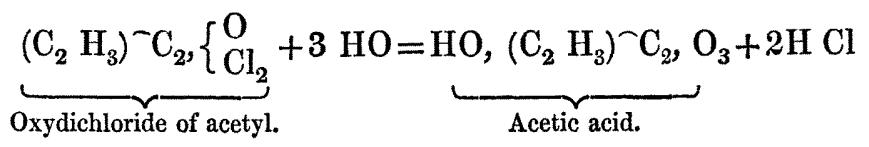

and its conversion into oxybisulphide of acetyl (éther bisulfuré), and oxysulphochloride of acetyl (éther chlorosulfuré), by the action of hydrosulphuric acid :

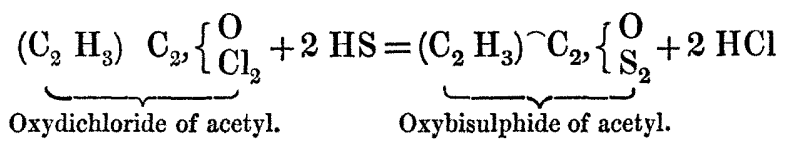

and

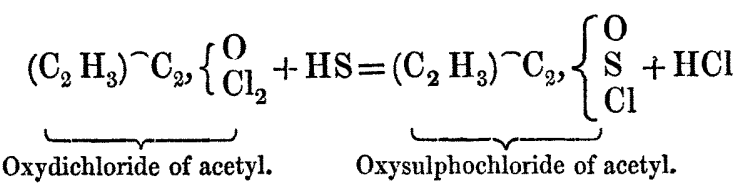

To these acetyl-combinations must still be added the dinoxamide of acetyl $\left(\mathrm{C}_{2} \mathrm{H}_{3}\right)^{-} \mathrm{C}_{2},\left\{\begin{array}{l}\mathrm{O}_{2} \\ \mathrm{NH}_{2}\end{array}\right.$, the formation of which, from acetate of oxide of ethyl and ammonia, is explained by the following equation :

$$
(\underbrace{\left.\mathrm{C}_{4} \mathrm{H}_{5}\right) \mathrm{O} \cdot\left(\mathrm{C}_{2} \mathrm{H}_{3}\right)-\mathrm{C}_{2}, \mathrm{O}_{3}}_{\text {Acetate of oxide of ethyl. }}+\mathrm{NH}_{3}=(\underbrace{\left.\mathrm{C}_{2} \mathrm{H}_{3}\right)-\mathrm{C}_{2},\left\{\mathrm{NH}_{2}\right.}_{\text {Acetamide. }}+\underbrace{\mathrm{O}_{2}}_{\text {Alcohol. }} \underbrace{\mathrm{C}_{4} \mathrm{H}_{5} \mathrm{O}}) \cdot \mathrm{HO}
$$

It can scarcely admit of a doubt that the product of decomposition of chloride of ethyl, corresponding to the dichlorinated oxide of ethyl, namely, the so-called dichlorinated chloride of ethyl, possesses a constitution similar to that of the former, and is therefore the true 
terchloride of acetyl, $*\left(\mathrm{C}_{2} \mathrm{H}_{3}\right)^{-} \mathrm{C}_{2}, \mathrm{Cl}_{3}$, although it exchanges its chlorine for oxygen with much greater difficulty, and requires long continued boiling with alcoholic potassa for its complete conversion into acetic acid.

By the action of chlorine on ether there is formed, according to Malaguti, in addition to the dichlorinated oxide of ethyl, a second body, the so-called semi-chlorinated ether, which Malaguti did not succeed in separating and purifying, respecting the existence of which, however, his experiments leave no doubt. This substance corresponds with the chloride of aldehyde, discovered by Regnault, in so far, that both may, from their empirical composition, be considered as ethylcompounds, the former as the oxide of ethyl, the latter as the chloride,

* The substance originally named chloride of acetyl, is the gaseous body $\left(\mathrm{C}_{4} \mathrm{H}_{3} \mathrm{Cl}\right)$, formed by the treatment of the oil of olefiant gas with alcoholic solution of potassa. The product obtained by the action of pentachloride of antimony on this gas, isomeric with the dichlorinated chloride of ethyl, has been named by Berzelius, superchloride of acetyl; to the dichlorinated chloride of ethyl itself, he has given the name, superchloride of paracetyl. It might appear from this, that the superchloride of acetyl of Berzelius, obtained from the oil of olefiant gas, was the true terchloride of acetyl, corresponding to acetic acid, while the so-called superchloride of paracetyl, obtained from chloride of ethyl, was only an isomeric compound, not really belonging to the acetyl-series. If it be considered, however, that the latter substance permits the replacement of its chlorine by oxygen, thus passing over into acetic acid, while the former cannot be directly converted into acetic acid, or any other member of the acetylseries, there can be no doubt, whatever, that the dichlorinated oxide of ethyl (superchloride of paracetyl) is the true acetyl-compound, namely, the terchloride of acetyl $\left(\mathrm{C}_{2} \mathrm{H}_{3}\right)^{-} \mathrm{C}_{2}, \mathrm{Cl}_{3}$.

The gas obtained by the action of alcoholic potassa upon olefiant gas, the so-called, chloride of acetyl appears to me to belong as little to the acetyl-series, as the socalled superchloride of acetyl. The isomerism of its supposed radical with acetyl, may however be easily explained, if we consider it, as hitherto, to be a body $\left(\mathrm{C}_{4} \mathrm{H}_{3}\right)$ homologous to allyl $\left(\mathrm{C}_{6} \mathrm{H}_{5}\right)$, for which I propose the name of vinyl, as suggestive of its origin (comp. Handworterbuch der Cheme, Bd. v. p. 548, ff). The olefiant gas may be considered as the hydrogen-compound of this radical, or as hydride of vinyl, consisting of $\frac{1}{2}$ volume of vinyl-vapour and $\frac{1}{2}$ volume of hydrogen, which corresponds perfectly with the observed specific gravity, assuming a condeusation of 2 vols. carbon-vapour and 3 rols. hydrogen to 1 volume, in vinyl:

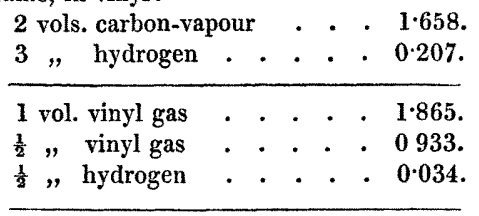

1 vol. hydride of vinyl . . 0.967.

Assuming with Liebig, the oil of olefiant gas to be a combination of hydrochloric acid with the chloride of the radical vinyl, and admitting the possibility of a substitution of 
in each of which one equivalent of hydrogen is replaced by one of chlorine :

$$
\begin{aligned}
& \left(\mathrm{C}_{4}\left\{\begin{array}{l}
\mathrm{H}_{4} \\
\mathrm{Cl}
\end{array}\right) \mathrm{O}\right. \text { semichlorinated ether, } \\
& \left(\mathrm{C}_{4}\left\{\begin{array}{l}
\mathrm{H}_{4} \\
\mathrm{Cl}
\end{array}\right) \mathrm{Cl}\right. \text { chloride of aldehyde. }
\end{aligned}
$$

As long, however, as this view is unsupported by facts, I consider it much more probable that these compounds possess a composition corresponding to the hydrochlorates of oxide of vinyl and of chloride of vinyl (comp. note, p. 376), being therefore combinations of hydrochloric acid with oxide of acetyl (in the semichlorinated ether), and chloride of acetyl (in the chloride of aldehyde) :

$$
\begin{aligned}
& \left(\mathrm{C}_{2} \mathrm{H}_{3}\right)-\mathrm{C}_{2}, \mathrm{O} \text {. } \mathrm{H} \mathrm{Cl} \text { semichlorinated ether, } \\
& \left(\mathrm{C}_{2} \mathrm{H}_{3}\right)-\mathrm{C}_{2}, \mathrm{Cl} \text {. } \mathrm{H} \mathrm{Cl} \text { chloride of aldehyde. }
\end{aligned}
$$

\begin{tabular}{|c|c|c|}
\hline $\begin{array}{r}\text { Vinyl }=\mathrm{C}_{4} \\
\text { Hydride of vinyl } \cdot \cdot \mathrm{C}_{4}\end{array}$ & $\begin{array}{l}\mathrm{H}_{3} \cdot \\
\left.\mathrm{H}_{3}\right) \mathrm{H}\end{array}$ & olefiant gas. \\
\hline $\left.\begin{array}{l}\text { Hydrochlorate of chlo- } \\
\text { ride of vinyl } . .\end{array}\right\}\left(\mathrm{C}_{4}\right.$ & $\left.\mathrm{H}_{3}\right) \mathrm{Cl}, \mathrm{H} \mathrm{Cl}$ & chloride of elayl (Berzelins). \\
\hline Chloride of vinyl & $\left.\mathrm{H}_{3}\right) \mathrm{Cl}$ & chloride of acetyl (Berzelius). \\
\hline $\begin{array}{l}\text { Hydrochlorate of chlo } \\
\text { ride of chlorovinyl }\end{array}$ & $\left.\begin{array}{l}\mathrm{H}_{2} \\
\mathrm{Cl}\end{array}\right) \mathrm{Cl}, \mathrm{H} \mathrm{Cl}$ & superchloride of acetyl (Berzelius). \\
\hline $\begin{array}{l}\text { Chloride of chlorovi } \\
\text { nyl . . . . }\end{array}$ & $\left.\mathrm{Cl}_{2}^{\mathrm{H}^{\prime}}\right)^{\mathrm{Cl}}$ & chloride of formyl (Berzelius). \\
\hline $\begin{array}{l}\text { Hydrochlorate of chlo- } \\
\text { ride of dichlorovinyl. }\end{array}$ & $\left.\begin{array}{l}\mathrm{H} \\
\mathrm{Cl}_{2}\end{array}\right) \mathrm{Cl}, \mathrm{H} \mathrm{Cl}$ & superchloride of formyl (Berzelius). \\
\hline $\begin{array}{l}\text { Hydrochlorate of chlo- } \\
\text { ride of trichlorovinyl. }\end{array}$ & $\left.\mathrm{Cl}_{3}\right) \mathrm{Cl}, \mathrm{H} \mathrm{Cl}$ & \\
\hline $\begin{array}{l}\text { Hydrochlorate of ox- } \\
\text { ide of vinyl }\end{array}$ & $\left.\mathrm{H}_{3}\right) \mathrm{O}, \mathrm{H} \mathrm{Cl}$ & oxychloride of elayl (B erzelius). \\
\hline $\begin{array}{l}\text { Hydrobromate of bro- } \\
\text { mide of vinyl }\end{array}$ & $\left.\mathrm{H}_{3}\right) \mathrm{Br}, \mathrm{H} \mathrm{Br}$ & bromide of elayl (Berzelius). \\
\hline $\left.\begin{array}{c}\text { Hydriodate of iodide } \\
\text { of vinyl }\end{array}\right\}$ & $\left.\mathrm{H}_{3}\right) \mathbf{I}, \mathbf{H ~ I}$ & iodide of elayl (Berzelius). \\
\hline Iodide of vinyl & $\left.\mathrm{H}_{3}\right) \mathbf{I}$ & iodide of acetyl (Berzelius). \\
\hline
\end{tabular}

the hydrogen in vinyl itself by chlorine, the composition of the substances derived from olefiant gas, may be best expressed by the following rational formulæ:

The conversion of the substance mentioned under the name of hydrochlorate of chloride of trichlorovinyl, and discovered by Pierre (Ann. Ch. Phys. [3] XXI. 439), into the so-called protochloride of carbon $\left(\mathrm{C}_{2} \mathrm{Cl}_{2}\right.$, or $\left.\mathrm{C}_{4} \mathrm{Cl}_{4}\right)$, by boiling with alcoholic potassa, is probably accompanied by an alteration in the arrangement of the elements, $\left(\mathrm{C}_{4} \mathrm{Cl}_{3}\right) \mathrm{Cl}$ to $\left(\mathrm{C}_{2} \mathrm{Cl}_{3}\right)-\mathrm{C}_{2}, \mathrm{Cl}$ (chloride of trichloracetyl), the latter formula expressing the rational composition of protochloride of carbon, as I shall presently endeavour to show.

The sulphur-compounds of vinyl require a more careful examination than they have hitherto been subjected to. The sulphides of elayl described by Löwig and Weidmann were doubtless impure substances, containing an admixture of sulphur. It might be interesting to examine the behaviour of chloride of vinyl with sulphocyanide of potassium, as a sulphocyanide of vinyl $\left(\mathrm{C}_{4} \mathrm{H}_{3}\right) \mathrm{Cy} \mathrm{S}_{2}$, col responding to oil of mustard $\left(\mathrm{C}_{6} \mathrm{H}_{5}\right) \mathrm{Cy} \mathrm{S}_{2}$, might possibly be produced under these circumstances. 
By this assumption, the formation of semi-chlorinated ether from oxide of ethyl :

$$
\underbrace{\mathrm{C}_{4} \mathrm{H}_{5} \mathrm{O}}_{\text {Oxide of ethyl. }}+2 \mathrm{Cl}=(\underbrace{\mathrm{C}_{2} \mathrm{H}_{3}}_{\text {Semichlorinated ether. }})^{-\mathrm{C}_{2}, \mathrm{O} . \mathrm{H} \mathrm{Cl}}+\mathrm{H} \mathrm{Cl}
$$

its conversion into oxybichloride of acetyl (bichlorinated oxide of ethyl) by treatment with chlorine:

$$
(\underbrace{\left(\mathrm{C}_{2} \mathrm{H}_{3}\right)-\mathrm{C}_{2}, \mathrm{O} . \mathrm{H} \mathrm{Cl}}_{\text {Semichlorinated ether. }}+2 \mathrm{Cl}=(\underbrace{\left.\mathrm{C}_{2} \mathrm{H}_{3}\right)-\mathrm{C}_{2},\left\{\begin{array}{l}
\mathrm{O} \\
\mathrm{Cl}_{2}
\end{array}\right.}_{\text {Oxybichloride of acetyl. }}+\mathrm{H} \mathrm{Cl}
$$

and its decomposition by water into aldehyde and hydrochloric acid.

$$
(\underbrace{\left.\mathrm{C}_{2} \mathrm{H}_{3}\right)^{-} \mathrm{C}_{2}, \mathrm{O} \cdot \mathrm{H} \mathrm{Cl}}_{\text {Semichlorinated ether. }}+\mathrm{HO}=\underbrace{\mathrm{HO} \cdot\left(\mathrm{C}_{2} \mathrm{H}_{3}\right)^{-} \mathrm{C}_{2}, \mathrm{O}}_{\text {Aldehyde. }}+\mathrm{H} \mathrm{Cl}
$$

may be explained in a simple and perfectly satisfactory manner.

It may be regarded as self-evident that a hypothesis constructed upon the constitution of acetic acid, or any other member of the series of fatty acids, must likewise admit of application to the remaining members of that series. If, therefore, we consider acetic acid as the oxide of the conjugate radical $\left(\mathrm{C}_{2} \mathrm{H}_{3}\right)^{-} \mathrm{C}_{2}$, it follows naturally that we must assume the existence of conjugate radicals analogous to acetyl, in propionic, valeric, margaric, formic acids, \&c. Indeed, in an attentive examination of these compounds, I have not met with any fact that was in contradiction with the above hypothesis; and I believe that I do not err in expressing the conviction that the compartment of the fatty acids, from formic acid up to melissic acid, and their manifold relations to other compounds, may be better interpreted by the above hypothesis than by any one of the former views. The decomposition of valeric acid by the galvanic current into butyl $\left(\mathrm{C}_{8} \mathrm{H}_{9}\right)$ and carbonic acid, and its formation from cyanide of butyl $\left(\mathrm{C}_{8} \mathrm{H}_{9}\right) \mathrm{C}_{2} \mathrm{~N}$ (valeronitril), are particularly well adapted to support this opinion.

The relation of stearic to margaric acid, and its bibasic nature, may be easily explained, without our being obliged to adopt the assertion made by Laurent and Gerhardt, that both these acids possess the same composition and saturating capacity, and are only two isomeric modifications, if we view stearic acid as a double acid, composed of two different oxides of margaryl $\left(\mathrm{C}_{32} \mathrm{H}_{33}\right)^{-} \mathrm{C}_{2}$, namely: $\mathrm{H} \mathrm{O} .\left(\mathrm{C}_{32} \mathrm{H}_{33}\right)^{-} \mathrm{C}_{2}, \mathrm{O}_{2}+\mathrm{H} \mathrm{O} \cdot\left(\mathrm{C}_{32} \mathrm{H}_{33}\right)^{-} \mathrm{C}_{2}, \mathrm{O}_{3}$-as: 


$$
2 \mathrm{HO} \cdot\left\{\begin{array}{llll}
\left(\mathrm{C}_{32}\right. & \left.\mathrm{H}_{33}\right) & -\mathrm{C}_{2}, \mathrm{O}_{3} \\
\left(\mathrm{C}_{32}\right. & \left.\mathrm{H}_{33}\right) & -\mathrm{C}_{2}, & \mathrm{O}_{3}
\end{array}\right\}=\text { Stearic acid. }
$$

I shall presently endeavour to establish the view that in a similar manner, sulphobenzoic, and sulphacetic acids are double acids, and owe their bibasic property to this circumstance.

According to the above hypothesis, the composition of the fatty acids would be expressed by the following rational formulæ :

\begin{tabular}{|c|c|}
\hline 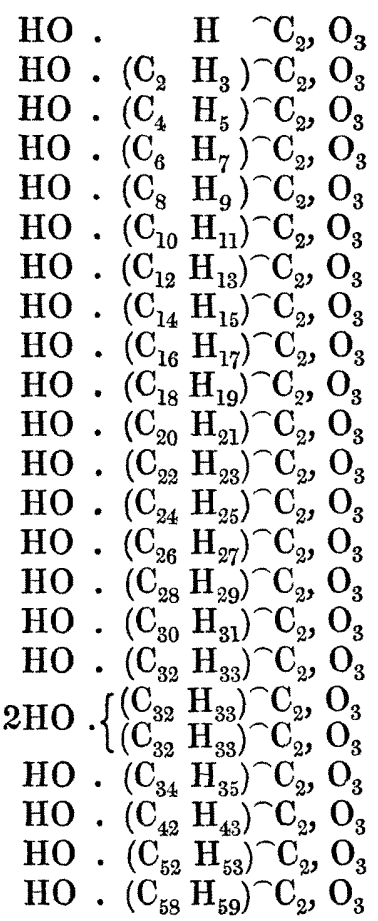 & $\begin{array}{l}\text { Formic acid. } \\
\text { Acetic acid. } \\
\text { Propionic acid. } \\
\text { Butyric acid. } \\
\text { Valeric acid. } \\
\text { Caproic acid. } \\
\text { Enanthylic acid. } \\
\text { Caprylic acid. } \\
\text { Pelargonic acid. } \\
\text { Caprinic acid. } \\
\text { Ricinostearic acid (margaritic acid). } \\
\text { Laurostearic acid (pichurimo-stearic acid). } \\
\text { Cocinic acid. } \\
\text { Myristic acid. } \\
\text { Benic acid. } \\
\text { Ethalic acid. } \\
\text { Margaric acid. } \\
\text { Stearic acid. } \\
\text { Bassic acid. } \\
\text { Behenic acid. } \\
\text { Cerotic acid. } \\
\text { Melissic acid. }\end{array}$ \\
\hline
\end{tabular}

A glance at the above table will show that the radicals of the fatty acids contain, as adjuncts, the radicals of the alcohols, of which, however, we are as yet acquainted with only a few, namely, methyl, ethyl, amyl, cetyl, and cerotyl. The important discovery made by Dumas, that the ammonia-salts of acetic, propionic, valeric, and other acids, may, in accordance with the deportment of formiate of ammonia, be converted, by distillation with phosphoric acid for instance, into the cyanogen-compounds of the adjuncts of these acids -for instance, cyanide of methyl, cyanide of ethyl, cyanide of propyl, and cyanide of butyl-furnishes us with the prospect of obtaining by this method the whole series of alcohols that are 
still wanting, provided we are successful in converting the cyanides into other combinations of the alcohol-radicals. The experiments hitherto made on this subject have, however, given no results.

Among the radicals of the fatty acids, formyl $\mathrm{H}^{\wedge} \mathrm{C}_{2}$ stands to a certain extent isolated, it being the only one in which the adjunct contains no carbon. As, however, its compounds bear the greatest resemblance to those of acetyl, this would appear to indicate that the nature of the adjuncts of conjugate radicals exercises comparatively little influence over the chemical character of their compounds.

The composition of those formyl-compounds, of which the constitution is established with tolerable certainty, may be expressed by the following rational formulæ:

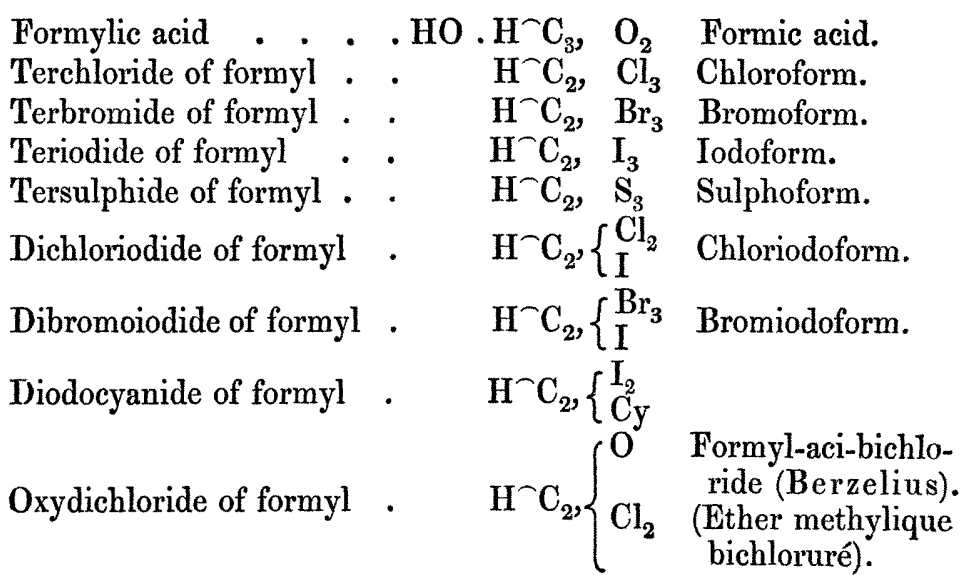

The analogy of hydrated oxide of methyl to hydrated oxide of ethyl, warrants the supposition that the former, in its oxidation and conversion into formic acid, undergoes a decomposition similar to that of the latter in its transformation into acetic acid; namely, that the elimination of $\mathrm{C}_{2} \mathrm{H}_{2}$ from the composition of methyl, precedes the production of formic acid from methyl-alcohol :

$$
(\underbrace{\left.\mathrm{C}_{2} \mathrm{H}_{3}\right) \mathrm{O} . \mathrm{HO}}_{\text {Hydrated oxide of methyl. }}+4 \mathrm{O}=\underbrace{\mathrm{HO} . \mathrm{H}^{-} \mathrm{C}_{2}}_{\text {Formylic acid. }}, \mathrm{O}_{3}+2 \mathrm{HO}
$$

In the same manner, the rational formula $\mathrm{H}^{-} \mathrm{C}_{2},\left\{\begin{array}{l}\mathrm{O} \\ \mathrm{Cl}_{2}\end{array}\right.$, or dichlorinated oxide of methyl, is based upon the supposition that when two equivalents of chlorine enter oxide of methyl in the place of two of hydrogen, it undergoes a metamorphosis correspond- 
ing to the conversion of oxide of ethyl into oxydichloride of acetyl, namely :

$$
\underbrace{\left(\mathrm{C}_{2} \mathrm{H}_{3}\right) \mathrm{O}}_{\text {Oxide of methyl. }}+4 \mathrm{Cl}=\underbrace{\mathrm{H}^{\frown} \mathrm{C}_{2},\left\{\begin{array}{l}
\mathrm{O} \\
\mathrm{Cl}_{2}
\end{array}\right.}_{\text {Oxydichloride of formyl. }}+2 \mathrm{H} \mathrm{Cl}
$$

Unfortunately, the chemical deportment of dichlorinated oxide of mythyl has been too little studied to admit of the deduction of any argument therefrom, for or against the above view; it can only be supposed, from its analogy with dichlorinated oxide of ethyl (oxydichloride of acetyl), that alcoholic potassa would convert it into formic acid and hydrochloric acid:

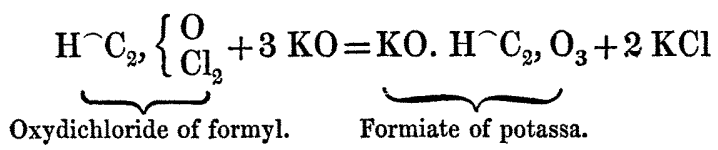

The view that the so-called perchlorinated ether, the pentachlorinated oxide of ethyl, no longer possessed the constitution of oxide of ethyl, was already defended, in opposition to the older theory of substitution, by Malaguti, in his excellent researches on the chlorinated ethers. Moreover, if we consider it established that chlorine, like oxygen, is capable of converting oxide of ethyl into an acetyl-compound, the pentachlorinated ether cannot really be a direct product of decomposition, and much less a substitution-product of oxide of ethyl, but must rather be considered as a derivative of oxydichloride of acetyl. Indeed, its most intimate relation to the acetyl-compounds may be inferred from its chemical comportment, and that of its products of decomposition, chloracetic acid, the so-called chloraldehyde, \&c. Even the fact that perchlorinated ether, chloracetic acid, chloraldehyde, chloroxethose, \&c., may be almost directly converted into acetic acid, and the latter again into chloracetic acid, renders it more than probable that all these bodies have a similar chemical constitution.

It becomes most clearly perceptible in the study of these compounds, into what a labyrinth of hypotheses, and to what very improbable assumptions we are forced, if we forsake, on the one hand, the theory of radicals, and adhere, on the other, to the immutability of organic radicals. It is certainly quite as difficult to agree with the hypotheses of Laurent and Dumas, as to adopt the views taken by Berzelius* of the constitution of perchlorinated 
ether and its derivatives, and of the substitution-products of the ethers in general.

I will endeavour to interpret these phenomena of substitution from the point of view above adopted, and to base the following considerations upon the hypothesis, that a substitution of chlorine for hydrogen takes place in the acetyl-radical, without dissolving the complex atom, three new secondary radicals being produced thereby, which contain, in the place of one, two, or three equivalents of hydrogen, a proportionate number of equivalents of chlorine, and which are gifted with properties similar to those of acetyl itself. For the better indication of their relations to the latter, I will assign to them the nameschloracetyl, dichloracetyl, trichloracetyl, and express their rational composition by the following formulæ :

$$
\begin{aligned}
& \text { Acetyl . . }\left(\mathrm{C}_{2} \mathrm{H}_{3}\right)^{-\mathrm{C}_{2}} \\
& \text { Chloracetyl . }\left(\mathrm{C}_{2}\left\{\begin{array}{l}
\mathrm{H}_{2} \\
\mathrm{Cl}^{2}
\end{array}\right)^{-\mathrm{C}_{2}}\right. \\
& \text { Dichloracetyl } \cdot\left(\mathrm{C}_{2}\left\{\begin{array}{l}
\mathrm{H} \\
\mathrm{Cl}_{2}
\end{array}\right)^{-\mathrm{C}_{2}}\right. \\
& \text { Trichloracetyl - }\left(\mathrm{C}_{2} \mathrm{Cl}_{3}\right)^{-\mathrm{C}_{2}}
\end{aligned}
$$

Of the various combinations of these three secondary acetyl-radicals, those of trichloracetyl have been by far the most accurately studied; I will therefore first submit them to examination.

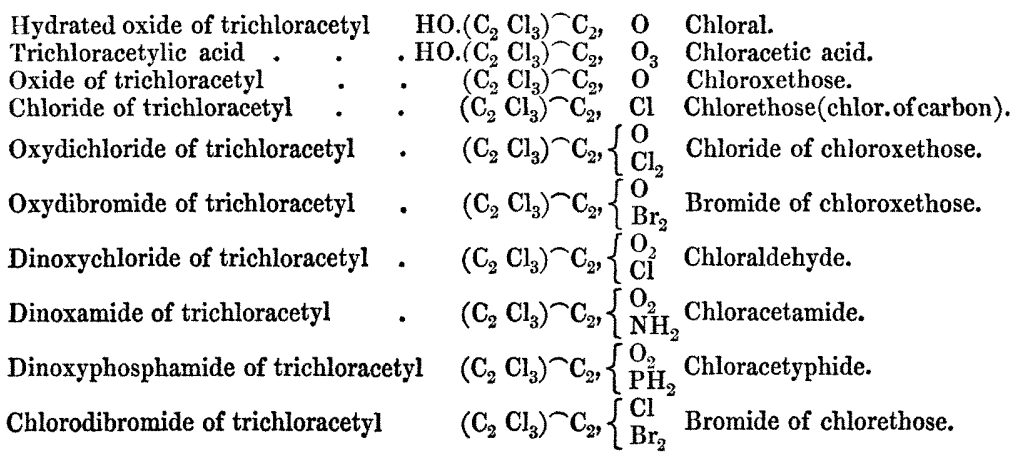

We may easily perceive that those of the trichloracetyl-compounds above-mentioned, which are also represented in the acetyl-series, differ in various points in their properties and chemical comportment from the corresponding members of the latter series. The acetyl has evidently undergone no unimportant modifications by the exchange of its hydrogen for chlorine. In these instances, as in the substitution-products of aniline, the chlorine, to however great an extent it 
appears to have lost its specific properties, imparts some portion of its chemical character to the combination in which it has entered the place of the hydrogen. This influence is rendered very distinctly evident in chloraniline and trichloraniline, by the weakening of the basic properties of the aniline; in the compounds of trichloracetyl it is not so obvious, although it is always rendered to a certain extent perceptible by a modification of the original affinities of acetyl. It should therefore not appear surprising, that chloracetic acid, when boiled, for instance, with potassa, deviates somewhat in its comportment from its analogue, acetic acid, or that oxydichloride of trichloracetyl (perchlorinated ether), the analogue of oxydichloride of acetyl (dichlorinated oxide of ethyl), should be decomposed with much greater difficulty, by similar treatment with potassa, than the latter. It is worthy of note, that the conversion of the chlorides (oxychlorides) of acetyl and trichloracetyl into the corresponding acids, is effected with greater ease, in proportion to the number of atoms of oxygen that the compound contains. While the terchloride of acetyl, which contains no oxygen, is but very slowly converted into acetic acid by boiling with alcoholic potassa, the oxydichloride of acetyl is converted into that acid with the greatest ease, by the mere action of water; and doubtless the dinoxychloride of acetyl, which is, as yet, unknown, but the production of which may be expected, with tolerable certainty, to result from the treatment of concentrated acetic acid with pentachloride of phosphorus, will be a liquid much more easily decomposed by water. On the other hand, dinoxychloride of trichloracetyl (chloraldehyde) is equally distinguished from the oxydichloride of trichloracetyl, by the facility with which it is converted into chloracetic acid.-Malaguti* has left it undecided whether the small quantity of formic acid, which he detected in the fluid, after continuous boiling of perchlorinated ether with alcoholic potassa, owed its production to the action of the potassa on the alcohol, or to the conversion of perchlorinated ether into cloracetic acid:

$$
(\underbrace{\left.\mathrm{C}_{2} \mathrm{Cl}_{3}\right)-\mathrm{C}_{3},\left\{\begin{array}{l}
\mathrm{O} \\
\mathrm{Cl}_{2}
\end{array}\right.}_{\text {Perchlorinated ether. }}+3 \mathrm{KO}=\underbrace{\mathrm{KO} \cdot\left(\mathrm{C}_{2} \mathrm{Cl}_{3}\right)-\mathrm{C}_{2}, \mathrm{O}_{3}}_{\text {Chloracetate of potassa. }}+2 \mathrm{KCl} .
$$

The simultaneous deposition of chloride of potassium gives, at any rate, a greater probability to the latter view.

The accompanying equations will show that, by the assumption of 
a trichloracetyl, the most simple and natural explanations are furnished :

1. Of the decomposition of chloracetic acid into terchloride of formyl and carbonic acid by boiling with potassa :

$$
\text { HO. } \underbrace{\left.\mathrm{C} \mathrm{C}_{2} \mathrm{Cl}_{3}\right)-\mathrm{C}_{2}}_{\text {Chloracetic acid. }}, \mathrm{O}_{3}+2 \mathrm{KO}=\underbrace{\mathrm{H}^{\frown} \mathrm{C}_{2}, \mathrm{Cl}_{3}}_{\text {Chloride of formyl. }}+2\left(\mathrm{KO} \mathrm{CO}_{2}\right) \text {. }
$$

2. Of the formation of chloracetamide by the action of ammonia on chloracetate of oxide of ethyl :

$$
\underbrace{\left(\mathrm{C}_{4} \mathrm{H}_{5}\right) \mathrm{O} .\left(\mathrm{C}_{2} \mathrm{Cl}_{3}\right)^{-} \mathrm{C}_{2}, \mathrm{O}_{3}}_{\text {Chloracetic ether. }}+\mathrm{NH}_{3}=\underbrace{\left(\mathrm{C}_{2} \mathrm{Cl}_{3}\right)^{-} \mathrm{C}_{2},\left\{\mathrm{O}_{2} \mathrm{NH}_{2}\right.}_{\text {Chloracetamide. }}+\underbrace{\left(\mathrm{C}_{4} \mathrm{H}_{5}\right) \mathrm{O} . \mathrm{HO}}_{\text {Alcohol. }}
$$

3. Of the conversion of chloracetate of ammonia by phosphoric acid into the substance, termed by its discoverers, Dumas, Malaguti, and Leblanc, chloracetonitrile, and which is probably a cyanogencompound $\left(\mathrm{C}_{2} \mathrm{Cl}_{3}\right) \cdot \mathrm{C}_{2} \mathrm{~N}$ :

$$
\underbrace{\mathrm{NH}_{4} \mathrm{O} \cdot\left(\mathrm{C}_{2} \mathrm{Cl}_{3}\right)-\mathrm{C}_{2}, \mathrm{O}_{3}}_{\text {Chloracetate of ammonia. }}+\mathrm{nPO}_{5}=\underbrace{\left(\mathrm{C}_{2} \mathrm{Cl}_{3}\right)^{-} \mathrm{C}_{2} \mathrm{~N}}_{\text {Chloracetonitrile. }}+4 \mathrm{HO}, \mathrm{nPO}_{5}
$$

4. Of the reproduction of chloracetic acid and ammonia from chloracetonitrile, by boiling with potassa :

$$
(\underbrace{\left.\mathrm{C}_{2} \mathrm{Cl}_{3}\right)-\mathrm{C}_{2} \mathrm{~N}+\mathrm{KO}}_{\text {Chloracetonitrile. }}+3 \mathrm{HO}=\underbrace{\mathrm{KO} .\left(\mathrm{C}_{2} \mathrm{Cl}_{3}\right)-\mathrm{C}_{2}}_{\text {Chloracetate of potassa. }}, \mathrm{O}_{3}+\mathrm{NH}_{3} \text {. }
$$

5. Of the transformation of perchlorinated ether, at a temperature of $300^{\circ} \mathrm{C}$., into sesquichloride of carbon and dinoxychloride of trichloracetyl (chloraldehyde) :

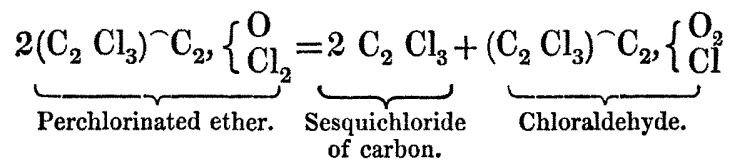

6. Of the metamorphosis which the latter body undergoes when heated with concentrated sulphuric acid:

$$
(\underbrace{\left.\mathrm{C}_{2} \mathrm{Cl}_{3}\right)^{-\mathrm{C}_{2}},\left\{\begin{array}{l}
\mathrm{O} \\
\mathrm{Cl}_{2}
\end{array}\right.}_{\text {Perchlorinated ether. }}+\mathrm{HO} . \mathrm{SO}_{3}=\underbrace{\left(\mathrm{C}_{2} \mathrm{C}_{3}\right)^{-} \mathrm{C}_{2}}_{\text {Chloraldehyde. }},\left\{\begin{array}{l}
\mathrm{O}_{2} \\
\mathrm{Cl}
\end{array}+\mathrm{HCl}+\mathrm{SO}_{3}\right.
$$

7. Of the decomposition of chloraldehyde by water into chloracetic acid and hydrochloric acid: 


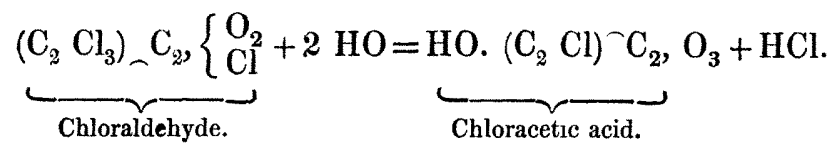

8. By alcohol into chloracetic ether and hydrochloric acid :

$$
\underbrace{\left(\mathrm{C}_{2} \mathrm{Cl}_{3}\right) \mathrm{C}_{2},\left\{\begin{array}{l}
\mathrm{O}_{2} \\
\mathrm{Cl}
\end{array}\right.}_{\text {Chloraldehyde. }}+\underbrace{\left(\mathrm{C}_{4} \mathrm{H}_{5}\right) \mathrm{O} . \mathrm{HO}}_{\text {Alcohol. }}=\underbrace{\mathrm{C}_{4}}_{\text {Chloracetic ether. }} \underbrace{\mathrm{H}_{5} \mathrm{O} .\left(\mathrm{C}_{2} \mathrm{Cl}_{3}\right)^{-} \mathrm{C}_{2}}, \mathrm{O}_{3}+\mathrm{HCl}
$$

9. By ammonia into chloracetamide:

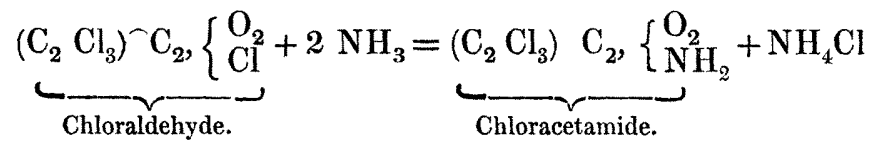

10. By terphosphide of hydrogen into chloracetyphide :

$$
(\underbrace{\left(\mathrm{C}_{2} \mathrm{Cl}_{3}\right)^{-} \mathrm{C}_{2},\left\{\begin{array}{l}
\mathrm{O}_{2} \\
\mathrm{Cl}
\end{array}\right.}_{\text {Chloraldehyde. }}+\mathrm{PH}_{3}=\underbrace{\left(\mathrm{C}_{2} \mathrm{Cl}_{3}\right)^{-} \mathrm{C}_{2},\left\{\begin{array}{l}
\mathrm{O}_{2} \\
\mathrm{PH}_{2}
\end{array}\right.}_{\text {Chloracetyphide. }}+\mathrm{HCl} .
$$

and finally, the formation of chloraldehyde by a simple change in the arrangement of the elements of the so-called perchloracetic ether, effected by passing the vapour of the latter through a dull, redhot tube:

$$
\underbrace{\left(\mathrm{C}_{4} \mathrm{Cl}_{5}\right) \mathrm{O},\left(\mathrm{C}_{2} \mathrm{Cl}_{3}\right)-\mathrm{C}_{2}}_{\text {Perchloracetic ether. }}, \underbrace{\mathrm{O}_{3}=2\left(\left(\mathrm{C}_{2} \mathrm{Cl}_{3}\right)-\mathrm{C}_{2},\left\{\begin{array}{l}
\mathrm{O}_{2} \\
\mathrm{Cl}
\end{array}\right)\right.}_{\text {Cloraldehyde. }}
$$

Chloraldehyde exhibits in its behaviour a remarkable similarity to the so-called chloride of benzoyl $\left(\mathrm{C}_{14} \mathrm{H}_{5} \mathrm{O}_{2} \mathrm{Cl}\right)$. The reason of this analogy between two such heterogeneous compounds may be easily arrived at, if the benzoyl-radical (free from oxygen) be viewed as a conjugate radical, like acetyl and trichloracetyl, having the rational formula $\left(\mathrm{C}_{12} \mathrm{H}_{5}\right) \mathrm{C}_{2}$. All three radicals possess in common the term $\mathrm{C}_{2}$, forming the real point of attack for the powers of affinity of the negative elements, while the adjuncts alone are different. Here, then, the subordinate part played by the adjuncts compared with that of the body with which they are conjugated, and their comparatively slight influence over the chemical nature of the compounds of conjugate radicals, is again most strikingly exhibited. The above similarity is, however, not merely confined to chlorobenzoyl and chloraldehyde, it exists equally between benzoic acid and chloracetic acid, benzamide and chloracetamide, benzonitrile and chloracetonitrile, and will doubt- 
less extend to the sulphide of benzoyl and cyanide of benzoyl, and the terms corresponding in the trichloracetyl series, with which we are yet acquainted. The analogy of these compounds is best rendered evident by the following comparison of their rational formulæ:
$\left(\mathrm{C}_{12} \mathrm{H}_{5}\right)-\mathrm{C}_{2}$
Benzoyl.
$\left(\mathrm{C}_{2} \mathrm{Cl}_{3}\right)^{\frown} \mathrm{C}_{2}$
Trichloracetyl.
HO. $\underbrace{\left(\mathrm{C}_{12} \mathrm{H}_{5}\right)-\mathrm{C}_{2}}_{\text {Benzoic acid. }}, \mathrm{O}_{3}$
HO. $\underbrace{\left(\mathrm{C}_{2} \mathrm{Cl}_{3}\right)-\mathrm{C}_{2}}_{\text {Chloracetic acid. }}, \mathrm{O}_{3}$
$\left(\mathrm{Ci}_{2} \mathrm{H}_{5}\right) \mathrm{C}_{2},\left\{\begin{array}{l}\mathrm{O}_{2} \\ \mathrm{Cl}\end{array}\right.$
Chlorobenzoyl.

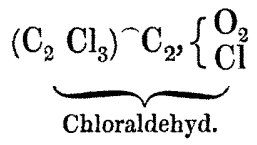
$\left(\mathrm{C}_{12} \mathrm{H}_{5}\right)-\mathrm{C}_{2},\left\{\begin{array}{l}\mathrm{O}_{2} \\ \mathrm{NH}_{2}\end{array}\right.$
Benzamide.
$(\underbrace{\left.\mathrm{C}_{12} \mathrm{H}_{5}\right) \cdot \mathrm{C}_{2} \mathrm{~N}}_{\text {Benzonitrile. }}$
$(\mathrm{C}_{2} \underbrace{\left.\mathrm{Cl}_{3}\right)-\mathrm{C}_{2},\left\{\begin{array}{l}\mathrm{O}_{2} \\ \mathrm{NH}_{2}\end{array}\right.}_{\text {Chloracetamide. }}$
$\underbrace{\left(\mathrm{C}_{2} \mathrm{Cl}_{3}\right) \cdot \mathrm{C}_{2} \mathrm{~N}}_{\text {Chloracetronitrile. }}$

The difference between the behaviour of oxydichloride of trichloracetyl (perchlorinated ether) with sulphide of potassium, and that of the corresponding member of the acetyl series (the oxydichloride of acetyl), is worthy of remark. Whilst the latter, when treated with hydrosulphuric acid, exchanges 1 or 2 equivalents of chlorine for sulphur, the former undergoes a simple reduction, by treatment with an alcoholic solution of sulphide of potassium, and is converted into the oily compound called by Malaguti, chloroxethose $\left(\mathrm{C}_{2} \mathrm{Cl}_{3}\right)^{-} \mathrm{C}_{2}, \mathrm{O}$ (oxide of trichloracetyl), sulphur and chloride of potassium being separated.

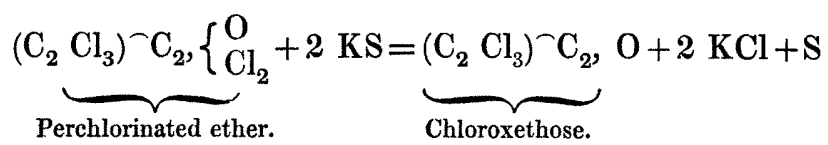

The mode of formation of chloroxethose, together with its property, when brought into contact with chlorine (or bromine), of combining directly with two equivalents of these elements, and thus being reconverted into perchlorinated ether (or the corresponding brominecompound $\left(\mathrm{C}_{2} \mathrm{Cl}_{3}\right)-\mathrm{C}_{2},\left\{\begin{array}{l}\mathrm{O} \\ \mathrm{Br}_{2}\end{array}\right.$ : 


$$
(\underbrace{\mathrm{C}_{2}}_{\text {Chloroxethose. }} \underbrace{\left.\mathrm{Cl}_{3}\right)-\mathrm{C}_{2}, \mathrm{O}}_{\text {Perchlorinated ether. }}+2 \mathrm{Cl}=\left(\mathrm{C}_{2}^{\mathrm{Cl}_{3}}\right),{ }^{\mathrm{C}_{2}},\left\{\begin{array}{l}
\mathrm{O} \\
\mathrm{Cl}_{2}
\end{array}\right.
$$

as also its comportment with chlorine in the presence of water, whereby it is partially converted into chloracetic acid :

$$
(\underbrace{\left.\mathrm{C}_{2} \mathrm{Cl}_{3}\right)^{-\mathrm{C}_{2}}, \mathrm{O}}_{\text {Chloroxethose. }}+2 \mathrm{Cl}+3 \mathrm{HO}=\underbrace{\mathrm{HO} .\left(\mathrm{C}_{2} \mathrm{Cl}_{3}\right)^{-} \mathrm{C}_{2}}_{\text {Chloracetic acid. }}, \mathrm{O}_{3}+2 \mathrm{H} \mathrm{Cl}
$$

are in perfect accordance with the view expressed by the above formula, namely, that chloroxethose is the oxide of trichloracetyl.

The above considerations lead to the conjecture, by no means unfounded, that the chloride of carbon $\mathrm{C} \mathrm{Cl}$ (Malaguti's chloride of chlorethose), which, in its comportment, exhibits so remarkable an analogy with oxide of trichloracetyl, is the chlorine-compound of the same radical, corresponding to this oxide, namely, chloride of trichloracetyl $\left(\mathrm{C}_{2} \mathrm{Cl}_{3}\right)^{-} \mathrm{C}_{2}$, Cl. We may perhaps even go farther, and regard the sesquichloride of carbon, obtained from this chloride of trichloracetyl by direct assimilation of chlorine, as the higher chlorinecompound of the same radical, namely, as terchloride of trichloracetyl $\left(\mathrm{C}_{2} \mathrm{Cl}_{3}\right)-\mathrm{C}_{2}, \mathrm{Cl}_{3}$, or at least assume the existence of two isomeric compounds, $\mathrm{C}_{2} \mathrm{Cl}_{3}$ (sesquichloride of carbon, trichloromethyl), and $\left(\mathrm{C}_{2} \mathrm{Cl}_{3}\right)-\mathrm{C}_{2}, \mathrm{Cl}_{3}$ (terchloride of trichloracetyl).

The principal objection against the assumption, that the chloride of carbon, produced by the combination of chloride of trichloracetyl with chlorine, is the terchloride of the latter radical, lies in the circumstance that we have not yet succeeded in replacing by oxygen the three equivalents of chlorine, considered as combined with trichloracetyl. Alcoholic solution of potassa is certainly not quite without action upon it, as, after continuous boiling, chloride of potassium is deposited, the liquid becoming brown; neither chloracetic acid, terchloride of formyl, nor formic acid, can, however, be found among the products of decomposition. It is possible that in this experiment, the terchloride of trichloracetyl gives off two equivalents of chlorine to the potassium, without any replacement ensuing, the oxygen of the latter attacking the alcohol and oxidizing it to aldehyde; this would also account for the brown colour assumed by the alcoholic potassasolution. It must, however, be borne in mind, that terchloride of acetyl too is only attacked with difficulty by bolling alcoholic potassa, and that the action of the latter is likewise obstinately withstood by the oxydichloride of trichloracetyl. On the other hand, the conjecture that the so-called chloride and sesquichloride of carbon are chlorine- 
compounds of trichloracetyl, is supported by a vast number of facts. The formation of the chloride of trichloracetyl from the so-called chloride of carbon, by passing the vapours of the latter through a redhot tube :

$$
\underbrace{4 \mathrm{C} \mathrm{Cl}_{2}}_{\begin{array}{c}
\text { Perchloride of } \\
\text { carbon. }
\end{array}}=\underbrace{\left.\mathrm{C}_{2} \mathrm{Cl}_{3}\right)-\mathrm{C}_{2}, \mathrm{Cl}}_{\begin{array}{c}
\text { Chloride of trichloro- } \\
\text { acetyl. }
\end{array}}+4 \mathrm{Cl}
$$

may be coupled with many similar examples, in which compounds poor in carbon, yield, by the action of a high temperature, less volatile substances richer in carbon, as, for instance, the formation of naphthalin, benzol, \&c. The solid chloride, obtained together with the chloride of trichloracetyl, doubtless owes its production to the further action of the large quantity of liberated chlorine upon the liquid chloride, and must therefore be considered as a secondary product of decomposition of the dichloride of carbon.

The remarkable similarity exhibited between the so-called sesquichloride of carbon and the oxydichloride of trichloracetyl (perchlorinated ether) in their outward appearance, as also in their behaviour with hydrosulphate of potassium, a point to which attention was first called by Malaguti, finds a surprisingly simple explanation in the assumption of the rational formulæ $\left(\mathrm{C}_{2} \mathrm{Cl}_{3}\right)^{-} \mathrm{C}_{2}, \mathrm{Cl}_{3}$, for the first named body. A simple comparison of the rational formulæ of these two substances:

$\left(\begin{array}{ll}\mathrm{C}_{2} & \mathrm{Cl}_{3}\end{array}\right)^{-} \mathrm{C}_{2},\left\{\begin{array}{l}\mathrm{O} \\ \mathrm{Cl}_{2}\end{array}\right.$ oxydichloride of trichloracetyl

$\left(\mathrm{C}_{2} \mathrm{Cl}_{3}\right)-\mathrm{C}_{2}, \quad \mathrm{Cl}_{3}$ terchloride of trichloracetyl (sesquichloride of carb.)

and of the corresponding members of the trichloracetyl-series that are poorer in chlorine, namely, of oxide of trichloracetyl and chloride of trichloracetyl :

$\left(\mathrm{C}_{2} \mathrm{Cl}_{3}\right)^{-} \mathrm{C}_{2}, \mathrm{O}$ oxide of trichloracetyl (chloroxethose Malaguti)

$\left(\mathrm{C}_{2} \mathrm{Cl}_{3}\right) \mathrm{C}_{2}, \mathrm{Cl}$ chloride of trichloracetyl (chlorethose Malaguti)

is only needed to account for the concordant behaviour of the two former compounds with hydrosulphate of sulphide of potassium, and of the two latter with chlorine and bromine, and particularly to explain the remarkable relations of the two latter to chloracetic acid. With regard to the transformation of chloride of trichloracetyl into chloracetic acid, by exposure to the action of chlorine in the presence of water, under the influence of solar light, it is partly due to the decomposition of water into hydrochloric acid and oxygen, and partly 
to the power possessed by chloride of trichloracetyl, of combining with oxygen directly, as it does with chlorine, at least when the former is in the nascent state. Dinoxychloride of trichloracetyl (chloraldehyde) is next formed, and this, being readily decomposed by water, is converted into chloracetylic acid.

$$
\underbrace{\left(\mathrm{C}_{2} \mathrm{Cl}_{3}\right)-\mathrm{C}_{2}, \mathrm{Cl}}_{\text {Chloride of trichloracetyl. }}+2 \mathrm{HO}+2 \mathrm{Cl}=(\underbrace{\left(\mathrm{C}_{2} \mathrm{Cl}_{3}\right)-\mathrm{C}_{2}}_{\text {Dinoxychloride of trichloracetyl. }},\left\{\begin{array}{l}
\mathrm{O}_{2} \\
\mathrm{Cl}
\end{array}+2 \mathrm{H} \mathrm{Cl}\right.
$$

$$
\underbrace{\left(\mathrm{C}_{2} \mathrm{Cl}_{3}\right)-\mathrm{C}_{2},\left\{\begin{array}{l}
\mathrm{O}_{2} \\
\mathrm{Cl}
\end{array}\right.}_{\begin{array}{c}
\text { Dinoxychloride of } \\
\text { trichloracetyl. }
\end{array}}+2 \mathrm{HO}=\underbrace{\mathrm{HO} \cdot\left(\mathrm{C}_{2} \mathrm{Cl}_{3}\right)-\mathrm{C}_{2}, \mathrm{O}_{3}}_{\text {Trichloracetyl. }}+\mathrm{H} \mathrm{Cl}
$$

The conversion of the greater part of the chloride of trichloracetyl into terchloride of trichloracetyl, in the above process, is doubtless owing to the slowness with which the oxygen is liberated from water by the chlorine.

If a similar condensation of the elements be assumed in trichloracetyl as in acetyl, one volume of trichloracetyl, containing therefore two volumes of carbon-vapour and three volumes of chlorine;

$$
\begin{aligned}
& 2 \text { vol. carbon-vapour . . . } 1.658 \\
& 3 \text {, chlorine . . . . . } 7 \cdot 346 \\
& 1 \text { vol. trichloracetyl . . . 9.004 }
\end{aligned}
$$

\begin{tabular}{|c|c|c|c|}
\hline $\begin{array}{l}\frac{1}{2} \text { vol. trichloracetyl } \\
\frac{1}{2}, \text { chlorine . }\end{array}$ & & & \\
\hline 1 vol. chloride of tri & hlo & rac & etyl \\
\hline$\frac{1}{2}$ vol. trichloracetyl & • & $\cdot$ & . \\
\hline$\frac{3}{2}$, chlorine . & - & - & . \\
\hline
\end{tabular}

and if the chloride of trichloracetyl and terchloride of trichloracetyl be regarded as containing, according to the usual modes of condensation, half a volume of trichloracetyl, combined respectively with half a volume or one and a half volume of chlorine, the calculation of the specific gravities of these bodies in the gaseous form, will furnish numbers, corresponding very closely with the observed vapour densities of the so-called protochloride of carbon $=5.82$ and sesquichloride of carbon $=8 \cdot 157$ : 
It is worth mentioning here, that the decomposition of oxydichloride of trichloracetyl into two equivalents of sesquichloride of carbon, and one equivalent of dinoxychloride of trichloracetyl, at a temperature of $300^{\circ} \mathrm{C}$., may be even more simply expressed by the following equation, than by the mode of viewing adopted at page 384 :

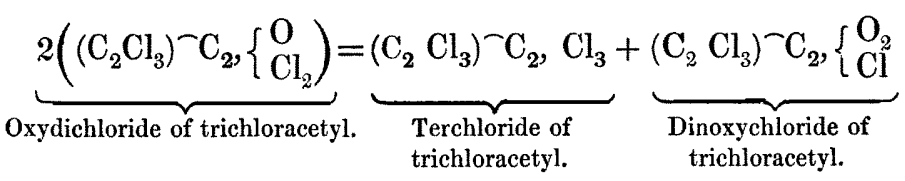

According to the view expressed in this equation, the metamorphosis of oxydichloride of trichloracetyl into terchloride and dinoxychloride, would be due to a simple transposition of the negative elements combined with the radical.

The remaining modes of formation of the chloride of trichloracetyl, for instance, by the action of chlorine on chloride of ethyl and hydrochlorate of cloride of vinyl (oil of olefiant gas), appear to me to accord likewise with the above assumption; in the first case, the terchloride of trichloracetyl is not formed as a direct product of decomposition of chloride of ethyl, but as a substitution-product of the terchloride of acetyl, into which the chloride of etbyl is first converted; in the second case, the formation of the terchloride is evidently preceded by that of the chloride of trichloracetyl, which may again be viewed as a product of decomposition of the hydrochlorate of chloride of trichlorovinyl $\left(\mathrm{C}_{4} \mathrm{Cl}_{3}\right) \mathrm{Cl}$. $\mathrm{HCl}$, lately discovered by Pier re, from which it is probably produced, in consequence of the separation of the apparently but loosely combined hydrochloric acid, by the transposition of the elements from $\left(\mathrm{C}_{4} \mathrm{Cl}_{3}\right) \mathrm{Cl}$ into $\left(\mathrm{C}_{2} \mathrm{Cl}_{3}\right)^{-} \mathrm{C}_{2}, \mathrm{Cl}$. (Compare the note, page 376.)

In speaking, some time back, of the chemical constitution of aldehyde and chloral,* I advanced the assumption that they might be conjugate combinations of formylous acid respectively with methyl and sesquichloride of carbon:

$$
\begin{array}{lllll}
\mathrm{C}_{2} & \mathrm{H}_{3} & \mathrm{C}_{2} & \mathrm{HO}_{2} & \text { aldehyde. } \\
\mathrm{C}_{2} & \mathrm{Cl}_{3} & \mathrm{C}_{2} & \mathrm{HO}_{2} & \text { chloral. }
\end{array}
$$

According to this view, by which the close relations of these two compounds is very well expressed, and a satisfactory interpretation given of the decomposition of chloral by alkalies into terchloride of 
formyl and formic acid, the oxidation, in the conversion of aldehyde into acetic, and of chloral into chloracetic acid, would extend to the common constituent, formylous acid, which would be transformed into conjugate oxalic acid, with formation of water. If, however, the readiness with which the elimination of hydrogen-equivalents proceeds, at least in aldehyde, be taken into consideration, it must appear strange that the action of chlorine should confine itself solely to the hydrogen of the adjunct, and that the formylous acid, so readily acted upon by oxygen, should remain unaltered. This difficulty is immediately overruled, by assuming, with Liebig, the pre-existence of a basic atom of water in chloral as well as in aldehyde, and by viewing the former as hydrated oxide of acetyl, and the latter as hydrated oxide of trichloracetyl :

$$
\begin{aligned}
& \text { HO. }\left(\mathrm{C}_{2} \mathrm{H}_{3}\right)-\mathrm{C}_{2}, \mathrm{O} \text { aldehyde. } \\
& \text { HO. }\left(\mathrm{C}_{2} \mathrm{Cl}_{3}\right)-\mathrm{C}_{2}, \mathrm{O} \text { chloral. }
\end{aligned}
$$

The formation of chloracetic acid, in the oxidation of chloral by means of fuming nitric acid, would then be, as in the conversion of aldehyde into acetic acid, the result of the direct assumption of two equivalents of oxygen :

$$
\text { HO } \underbrace{\left(\mathrm{C}_{2} \mathrm{Cl}_{3}\right)-\mathrm{C}_{2}}_{\text {Chloral. }}, \mathrm{O}+2 \mathrm{O}=\underbrace{\mathrm{HO} .\left(\mathrm{C}_{2}\right.}_{\text {Chloracetic acid. }} \underbrace{\left.\mathrm{Cl}_{3}\right)} \mathrm{C}_{2}, \mathrm{O}_{3}
$$

This hypothesis likewise furnishes a proper explanation of the decomposition of chloral, by solution of potassa, into formic acid and terchloride of formyl, as is shown by the following equation :

$$
\text { HO. } \underbrace{\left(\mathrm{C}_{2} \mathrm{Cl}_{3}\right)^{-} \mathrm{C}_{2}}_{\text {Chloral. }}+\mathrm{KO} . \mathrm{HO}=\underbrace{\mathrm{KO} . \mathrm{H}^{-} \mathrm{C}_{2}}_{\begin{array}{c}
\text { Formiate of } \\
\text { potassa. }
\end{array}}, \mathrm{O}_{3}+\underbrace{\mathrm{H}^{-} \mathrm{C}_{2}, \mathrm{Cl}_{3}}_{\begin{array}{c}
\text { Terehloride of } \\
\text { formyl. }
\end{array}}
$$

With regard to the interesting metamorphosis which hydrate of chloral undergoes by treatment with sulphuric acid, other expressions may be easily given of the composition of chloralide, accounting equally well for its formation and chemical comportment as the formula $2 \mathrm{C}_{2} \mathrm{HCl}_{3} \cdot 3 \mathrm{C}_{2} \mathrm{O}_{2}$ constructed by Städeler,* which it is difficult to bring into accordance with the above view of the constitution of chloral. It might, with equal justice, be considered as a combination of two equivalents of oxide of trichloracetyl with one equivalent of hydrate of formic acid $=2\left[\left(\mathrm{C}_{2} \mathrm{Cl}_{3} \cdot \mathrm{C}_{2}, \mathrm{O}\right)\right]+\mathrm{HO} . \mathrm{H}^{-} \mathrm{C}_{2}, \mathrm{O}_{3}$, or as a double 
compound of chloral and formiate of the oxide of trichloracetyl $=$ HO. $\left(\mathrm{C}_{2} \mathrm{Cl}_{3}\right)^{-} \mathrm{C}_{2}, \mathrm{O}+\left(\mathrm{C}_{2} \mathrm{H}_{3}\right)^{-} \mathrm{C}_{2}, \mathrm{O} \cdot \mathrm{H}^{-} \mathrm{C}_{2}, \mathrm{O}_{3}$. It is left for future researches to decide which of these formulæ can claim the advantage, or which view of the rational composition of chloralide is the correct one.

It has already been stated that we are as yet only acquainted with a few compounds of the intermediate secondary acetyl-radicals preceding trichloracetyl, namely, chloracetyl $\left(\mathrm{C}_{2}\left\{\begin{array}{l}\mathrm{H}_{2} \\ \mathrm{Cl}^{2}\end{array}\right)-\mathrm{C}_{2}\right.$, and dichloracetyl $\left(\mathrm{C}_{2}\left\{\begin{array}{l}\mathrm{H} \\ \mathrm{Cl}_{2}\end{array}\right)-\mathrm{C}_{2}\right.$. One of the most interesting is the acid of chloracetyl, corresponding to that of trichloracetyl, namely, chloracetylic acid HO. $\left(\mathrm{C}_{2}\left\{\begin{array}{l}\mathrm{H}_{2} \\ \mathrm{Cl}^{2}\end{array}\right)-\mathrm{C}_{2}, \mathrm{O}_{3}\right.$, which Leblanc* prepared by the action of dry chlorine-gas on concentrated acetic acid in diffused daylight.

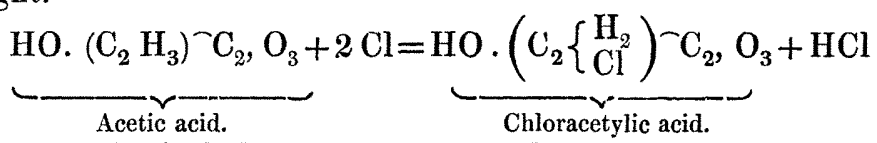

We must also include, among these bodies, the two substitutionproducts of terchloride of acetyl, described by Regnault, $\uparrow$ and resulting, together with chloride of acetyl, from the decomposition of the so-called chloride of aldehyde (first substitution-product of chloride of ethyl), namely, the terchloride of chloracetyl $\left(\mathrm{C}_{2}\left\{\begin{array}{l}\mathrm{H}_{2} \\ \mathrm{Cl}^{2}\end{array}\right)-\mathrm{C}_{3}, \mathrm{Cl}_{3}\right.$, (trichlorinated chloride of ethyl), and terchloride of dichloracetyl $\left(\mathrm{C}_{2}\left\{\begin{array}{l}\mathrm{H} \\ \mathrm{Cl}_{2}\end{array}\right)-\mathrm{C}_{2}, \mathrm{Cl}_{3}\right.$ (tetrachlorinated chloride of ethyl.) The substitution-products corresponding to oxydichloride of acetyl, namely, the oxydichlorides of chloracetyl and dichloracetyl, have not yet been obtained.

The vapour-densities of terchloride of acetyl $(=4.530)$, of terchloride of chloracetyl $(=5 \cdot 799)$, of terchloride of dichloracetyl $(=6.983)$, and terchloride of trichloracetyl $(=8.157)$, as determined by Regnault, are in perfect accordance with the above assumption, if we consider $\frac{1}{2}$ vol. of each of the radicals of these bodies combined with $\frac{3}{2}$ vol. of chlorine to form 1 volume, according to the usual mode of condensation.

$$
\text { Acetyl }\left(\mathrm{C}_{2} \mathrm{H}_{3}\right)^{-} \mathrm{C}_{2} \text {. }
$$

Terchloride of acetyl $\left(\mathrm{C}_{2} \mathrm{H}_{3}\right)-\mathrm{C}_{2}, \mathrm{Cl}_{3}$.

2 vols. carbon vapour. . 1.658 $\frac{1}{2}$ vol. acetyl gas . . . . 0.932

\begin{tabular}{l}
$3 \%$ hydrogen . . $.0 \cdot 207$ \\
\hline 1 vol. acetyl . . . . 1.865
\end{tabular}$\frac{\frac{3}{2}, \text { chlorine . . . . } 3 \cdot 604}{1 \text { vol. terchloride of acetyl. } 4 \cdot 536}$

* Ann. Chim. Phys. [3] LXXI, 353.

(found . 4.530)

+ Ibid, X. 212. 
Chloracetyl $\left(\mathrm{C}_{2}\left\{\begin{array}{l}\mathrm{H}_{2} \\ \mathrm{Cl}^{\prime}\end{array}\right\} \mathrm{C}_{2}\right.$.

2 vols. carbon-vapour. . 1.658

2 , hydrogen . . . 0.138

1 vol. chlorine . . . 24449

1 vol. chloracetyl . . . 4:247

Dichloracetyl $\left(\mathrm{C}_{2}\left\{\begin{array}{l}\mathrm{H}_{2} \\ \mathrm{Cl}\end{array}\right)-\mathrm{C}_{2}\right.$

2 vols. carbon-vapour $\cdot 1 \cdot 658$

1, hydrogen . . . 0.069

2 , chlorine . . . 4.898

1 vol. dichloracetyl . . 6.628

Trichloracetyl $\left(\mathrm{C}_{2} \mathrm{Cl}_{3}\right)-\mathrm{C}_{2}$.

2 vols. carbon-vapour . $1 \cdot 658$

3 , chlorine . . . $7 \cdot 346$

1 vol. trichloracetyl . . 9.004
Terchloride of chloracetyl $\left(\mathrm{C}_{2}\left\{\begin{array}{l}\mathrm{H} \\ \mathrm{Cl}\end{array}\right) \widehat{C}_{2} \mathrm{O}, \mathrm{Cl}_{3}\right.$ $\frac{1}{2}$ vol. chloracetyl-gas . . $2 \cdot 123$

$\frac{3}{2}$, chlorine . . . $3 \cdot 672$

1 vol. terchloride of chloracetyl . . . . . $5 \cdot 795$

(found . 5.799)

Chloride of dichloracetyl : $\left(\mathrm{C}_{2}\left\{\begin{array}{l}\mathrm{H} \\ \mathrm{Cl}_{3}\end{array}\right)-\mathrm{C}_{2}, \mathrm{C}\right.$

$\frac{1}{2}$ vol. dichloracetyl-gas . $.3 \cdot 314$

$\frac{9}{2}$, chlorine . . . . 3.672

1 vol. chlor. of dichloracetyl $6 \cdot 986$

(found . 6.983)

Chloride of trichloracetyl $\left(\mathrm{C}_{2} \mathrm{Cl}_{3}\right)-\mathrm{C}_{2}, \mathrm{Cl}_{3}$. $\frac{1}{2}$ vol. trichloracetyl-gas $\cdot 4 \cdot 502$ $\frac{3}{2}$, chlorine . . . 3672

1 vol. chlor. of trichloracetyl $8 \cdot 174$

(found . 8*157)

The metamorphoses which chloride of ethyl undergoes consecutively by the action of chlorine, may be exhibited by the following formulæ of the resulting products of decomposition :

Protochloride of ethyl . . $\left.\quad . \quad \begin{array}{llll}C_{4} & \mathrm{H}_{5}\end{array}\right) \quad \mathrm{Cl}$. . éther hydrochlorique

Hydrochlorate of protochloride of acetyl $\left(\mathrm{C}_{2} \mathrm{H}_{3}\right)^{-} \mathrm{C}_{2}, \mathrm{Cl}, \mathrm{HCl}\{$ éther hydrochlor.

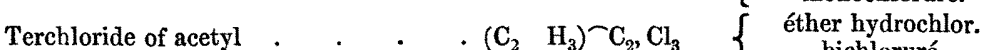

Terchloride of chloracetyl . . . $\left(\mathrm{C}_{2}\left\{\mathrm{H}_{3}\right)-\mathrm{C}_{2}, \mathrm{Cl}_{3}\right\}$ éther hydrochlor.

Terchloride of dichloracetyl . . . $\left(\mathrm{C}_{2}\left\{\begin{array}{l}\mathrm{H}_{3} \\ \mathrm{Cl}_{2}\end{array}\right)-\mathrm{C}_{2}, \mathrm{Cl}_{3}\right\}$ éther hydrochlor.

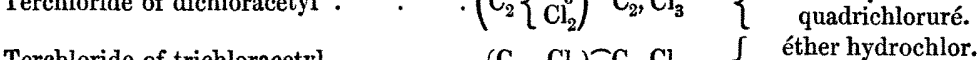

Terchloride of trichloracetyl . $\cdot\left(\mathrm{C}_{2} \mathrm{Cl}_{3}\right)^{-} \mathrm{C}_{2}, \mathrm{Cl}_{3} \quad\left\{\begin{array}{r}\text { éther hydrochlor } \\ \text { perchloruré. }\end{array}\right.$

It still remains for us to discuss the chemical constitution of those bodies, which are produced by substitution from the combinations of the other radicals homologous with acetyl. With regard to chlorobutyric and chlorovaleric acid, as also to nitropropionic acid, the assumption of the conjugate radicals $\left(\mathrm{C}_{4} \mathrm{H}_{5}\right)^{-} \mathrm{C}_{2},\left(\mathrm{C}_{6} \mathrm{H}_{7}\right)^{-} \mathrm{C}_{2}$, and $\left(\mathrm{C}_{8} \mathrm{H}_{9}\right)^{-} \mathrm{C}_{2}$ in propionic, butyric, and valeric acids, and the analogy of these substances with acetic acid, scarcely admit any other explanation of the above processes of substitution than that the 
hydrogen in the adjuncts of these radicals is substituted by chlorine, hyponitric acid, \&c., new secondary radicals being thus produced, which still possess the constitution of the primary radicals. Hence, the composition of nitropropionic, chlorobutyric, and chlorovaleric acids, is expressed by the following rational formulæ.

$$
\begin{aligned}
& \mathrm{HO} \cdot\left(\mathrm{C}_{4}\left\{\begin{array}{l}
\mathrm{H}_{4} \\
\mathrm{NO}_{4}
\end{array}\right)-\mathrm{C}_{2} \mathrm{O}_{3}\right. \text { Nitropropionic acid. } \\
& \mathrm{HO} \cdot\left(\mathrm{C}_{6}\left\{\begin{array}{l}
\mathrm{H}_{5} \\
\mathrm{Cl}_{2}
\end{array}\right)-\mathrm{C}_{2}, \mathrm{O}_{3}\right. \text { Dichlorobutyric acid. } \\
& \mathrm{HO} \cdot\left(\mathrm{C}_{6}\left\{\begin{array}{l}
\mathrm{H}_{3} \\
\mathrm{Cl}_{4}
\end{array}\right)-\mathrm{C}_{2}, \mathrm{O}_{3}\right. \text { Quadrichlorobutyric acid. } \\
& \mathrm{HO} \cdot\left(\mathrm{C}_{8}\left\{\begin{array}{l}
\mathrm{H}_{7} \\
\mathrm{Cl}_{2}
\end{array}\right)-\mathrm{C}_{2}, \mathrm{O}_{3}\right. \text { Dichlorovaleric acid. } \\
& \mathrm{HO} \cdot\left(\mathrm{C}_{8}\left\{\begin{array}{l}
\mathrm{H}_{5} \\
\mathrm{Cl}_{4}
\end{array}\right)-\mathrm{C}_{2}, \mathrm{O}_{3}\right. \text { Quadrichlorovaleric acid. }
\end{aligned}
$$

It is much more difficult to explain satisfactorily the metamorphoses which the formyl-compounds undergo by the action of chlorine. Although I do not dispute the existence of a secondary formylradical of the composition $\mathrm{Cl}^{-} \mathrm{C}_{2}$, but am, on the contrary, convinced of its existence in chlorinated formiate of oxide of ethyl, and of oxide of methyl, yet the assumption of its existence in the substitutionproducts of the simple formyl-compounds, for instance, in chlorinated chloride of formyl, oxydichloride of formyl, \&c., appears to me exceedingly bold and improbable. Even the behaviour of hydrated formic acid with chlorine, by which it is converted not into chloroformic $\left(\mathrm{HO} . \mathrm{Cl}^{-} \mathrm{C}_{2}, \mathrm{O}_{3}\right)$, but into hydrochloric and carbonic acids, unmistakeably indicates the action of affinities different from those exerted in compounds, the radicals of which contain a carbohydrogen as adjunct. Terchloride of formyl undergoes an analogous decomposition, being split up, as is well known, into two equivalents of perchloride of carbon by the action of chlorine :

$$
\underbrace{\mathrm{H}^{-} \mathrm{C}_{2}, \mathrm{Cl}_{3}}+2 \mathrm{Cl}=\underbrace{2 \mathrm{C} \mathrm{Cl}_{2}}+\mathrm{H} \mathrm{Cl}
$$

Terchloride of formyl. Perchloride of carbon.

It would at any rate be difficult to deduce from the chemical comportment of perchloride of carbon, any argument in favour of that substance being terchloride of chloroformyl $\left(\mathrm{Cl}^{-} \mathrm{C}_{2}, \mathrm{Cl}_{3}\right)$, or chloride of trichloromethyl $\left(\mathrm{C}_{2} \mathrm{Cl}_{3}, \mathrm{Cl}\right)$, or of its possessing any other rational formula.-The chlorinated oxydichloride of formyl (the final product of the action of chlorine on oxide of methyl, having the empirical formula $\mathrm{C}_{2} \mathrm{Cl}_{3} \mathrm{O}$ ), has been unfortunately too little studied to afford, by its comportment, any conclusion as to its constitution. It may, perhaps, 
be a simple combination of perchloride of carbon with chlorocarbonic acid, having the rational formula $\mathrm{C} \mathrm{Cl}_{2}, \mathrm{C}^{-}\left\{\begin{array}{l}\mathrm{O} \\ \mathrm{Cl} \text {. }\end{array}\right.$ This product appears at any rate no longer to possess the constitution of oxide of methyl, nor of oxybichloride of formyl; at least, the observation made by Regnault, that the condensation of the socalled oxide of perchloro-methyl in the gaseous form is only half as great as that of the compound from which it is directly derived, appears to indicate that the conversion of oxydichloride of formyl (dichlorinated oxide of methyl) into oxide of perchloromethyl is accompanied by a change in the relative position of the atoms.

It is at present impossible to decide whether the final product of the action of chlorine on sulphide of methyl is analogous in composition to the foregoing substance, or whether its composition may be expressed by the rational formula $\mathrm{C} \mathrm{Cl}_{2} . \mathrm{C}\left\{\begin{array}{l}\mathrm{S} \\ \mathrm{Cl}\end{array}\right.$

Malaguti,* in his admirable researches on the chlorinated ethers, was the first to advance, and support with powerful arguments, the view that the various compound chlorinated ethers examined by him (in which all the hydrogen was substituted by chlorine), contain no perchlorinated ether, in the form in which it is known in the isolated state (oxydichloride of trichloracetyl), but that they more probably have the same constitution as the normal ethers of which they are the derivatives. The composition of perchloracetic ether would then be expressed by the rational formula $\left(\mathrm{C}_{4} \mathrm{Cl}_{5}\right) \mathrm{O},\left(\mathrm{C}_{2} \mathrm{Cl}_{3}\right)^{-} \mathrm{C}_{2}, \mathrm{O}_{3}$. If it were assumed, on the other hand, that the oxide of ethyl, in acetic ether, in its conversion into perchloracetic ether underwent the same metamorphosis as it does in the free state, namely, that it was converted thereby into oxydichloride of trichloracetyl

$$
\left(\mathrm{C}_{2} \mathrm{Cl}_{3}\right)-\mathrm{C}_{2},\left\{\begin{array}{l}
\mathrm{O} \\
\mathrm{Cl}_{2}
\end{array}\right.
$$

the perchloracetic ether would then have to be viewed as trichloracetate of oxydichloride of trichloracetyl $=$

$$
\left(\mathrm{C}_{2} \mathrm{Cl}_{3}\right)^{-} \mathrm{C}_{2},\left\{\begin{array}{l}
\mathrm{O} \\
\mathrm{Cl}_{2} .
\end{array}\left(\mathrm{Cl}_{2} \mathrm{Cl}_{3}\right)^{-} \mathrm{C}_{2}, \mathrm{O}_{3} .\right.
$$

Irrespective of the arguments maintained by Malaguti against the existence of perchlorinated ether, as it is known in the free state, in perchloracetic ether, it appears to me in itself but slightly probable that, in a metamorphosis so completely altering the molecular arrangement of atoms, as, for instance, in the conversion of carbonate of oxide of ethyl $\left(\mathrm{C}_{4} \mathrm{H}_{5}\right)\left(\mathrm{O}, \mathrm{CO}_{2}\right.$, into carbonate of oxydichloride of 


\section{trichloracetyl $\left(\mathrm{C}_{2} \mathrm{Cl}_{3}\right)^{-} \mathrm{C}_{2} \cdot\left\{\begin{array}{l}\mathrm{O} \\ \mathrm{Cl}_{2}\end{array} \mathrm{CO}_{2}\right.$, the two members-carbonic} acid and oxydichloride of trichloracetyl should remain combined. The objection may be raised here, that it is still enigmatical why the action of chlorine on oxide of ethyl, combined with acids, produces no change in the molecular arrangement of the atoms, while free oxide of ethyl, under similar circumstances, immediately passes into an acetyl-compound; this may be answered by referring to the many cases in which a compound owes its existence olely to its combination with another body, or even to the mere presence of such a substance. Carbamic acid, cyanic acid, and many others, are well known to exist only in combination with bases; they split up on the moment of their liberation into simpler groups of atoms. We know, likewise, that the addition of a few drops of solution of potassa to the neutral aqueous solution of a large quantity of sulphovinate of potassa, is sufficient to prevent perfectly the easy decomposition of that substance by boiling. If, moreover, the view be adopted without hesitation, that in hyposulphobenzolic and napthalic acids, the hyposulphuric acid assumed as existing therein, acquires a stability perfectly foreign to it when in the free state, by the assimilation of the adjunct, it is certainly not less justifiable to assume that the elements of oxide of ethyl in compound ethers, are held together with a greater force, by their combination with acids, than is the case with free oxide of ethyl, so that the original grouping of atoms remains the same, even if chlorine be replaced for all the hydrogen-equivalents of a compound ether. The property possessed by so many binary compounds, of gaining increased stability by their combination with a third body, may be compared to the action of a powerful magnet on two weaker ones, which alone have not power sufficient to support each other, but to which this power is imparted on the approach of a more powerful magnet.

It must not, however, be considered strange that we have not as yet succeeded, and perhaps never shall be successful, in converting the chlorinated compound ethers into the normal ethers by a process similar to that by which chloracetic acid is reconverted into acetic acid, and chloraniline into aniline. The attachment of their constituents, the chlorinated acid and the chlorinated oxide of ethyl, appears weakened to such a degree by the entrance of chlorine in the place of hydrogen, that a comparatively slight impulse, such as is imparted by the action of heat, alkalis, alcohol, \&c., is required to effect an essential change in the molecular arrangement of their atoms. All the endeavours to reproduce the original compounds 
from the chlorinated ethers have met with no result, and it is probable that the slight stability of the latter compounds will always present an insurmountable obstacle to the success of such experiments.

The highly interesting and numerous metamorphoses of chlorinated compound ethers, for the knowledge of which we are principally indebted to Malaguti and Cahours, furnish undoubtedly the most appropriate means of deciding the question of the rational composition of the latter substances. We will therefore examine the explanation furnished of these phenomena, by the above mode of viewing.

The metamorphoses of the various chlorinated ethers containing chlorinated oxide of ethyl, by potassa, ammonia, alcohol, methylalcohol, \&c., exhibit a remarkable analogy in the circumstance that the resulting products of decomposition are the same as would be furnished by a combination, or a mixture, of the particular (chlorinated) acid with dinoxychloride of trichloracetyl (chloraldehyde). It may hence be assumed with tolerable certainty that the contact of these substances with the above agents, always effects, in the first instance, their separation into the two groups of atoms composing them, namely, into chlorinated oxide of ethyl and the chlorinated acid. It appears, however, that a chlorinated oxide of ethyl cannot exist as such, but exhibits a tendency to pass over into the metameric compound, oxydichloride of trichloracetyl $\left(\mathrm{C}_{2} \mathrm{Cl}\right)^{-} \mathrm{C}_{2},\left\{\begin{array}{l}\mathrm{O} \\ \mathrm{Cl}_{2}\end{array}\right.$, while the acids, separated from chlorinated oxide of ethyl (with the exception of carbonic acid), cannot exist in the anhydrous state. It is therefore probable that, at the moment of separation, an exchange is effected of one equivalent of oxygen for one of chlorine in the chlorinated oxide of ethyl, while it undergoes the above metamorphosis; whereby there is formed, on the one hand, an oxychloride corresponding to the hypothetically anhydrous acid, or a direct product of decomposition, produced by a transposition of the atoms, and, on the other hand, dinoxychloride of trichloracetyl. This metamorphosis may be best understood by means of the following general equation, in which Ac represents the acid-radical :

$$
\begin{aligned}
& \left(\mathrm{C}_{4} \mathrm{Cl}_{5}\right) \text { O. } \mathrm{Ac} \mathrm{O}_{3}=\left(\mathrm{C}_{2} \mathrm{Cl}_{3}\right)^{-} \mathrm{C}_{2}\left\{\begin{array}{l}
\mathrm{O} \\
\mathrm{Cl}_{2}
\end{array}+\mathrm{AcO}_{3}\right. \\
& =\left(\mathrm{C}_{2} \mathrm{Cl}_{3}\right)^{-} \mathrm{C}_{2},\left\{\begin{array}{l}
\mathrm{O}_{2} \\
\mathrm{Cl}
\end{array}+\mathrm{Ac}\left\{\begin{array}{l}
\mathrm{O}_{2} \\
\mathrm{Cl}
\end{array}\right.\right.
\end{aligned}
$$

Indeed, the term $\left(\mathrm{C}_{2} \mathrm{Cl}_{3}\right) \mathrm{C}_{2},\left\{\begin{array}{l}\mathrm{O} \\ \mathrm{Cl}_{2}\end{array}\right.$ (the so-called chloraldehyde) is found to be a constant product of decomposition, by heat, of all com- 
pound ethers containing chlorinated oxide of ethyl, accompanied by a compound corresponding in composition to the formula $\mathrm{Ac}\left\{\begin{array}{l}\mathrm{O}_{2} \\ \mathrm{Cl} \text {, or at }\end{array}\right.$ least by a direct product of decomposition of the latter. The chlorinated ethers of oxıde of methyl undergo a perfectly analogous metamorphosis, with the only difference that, in this case, chlorocarbonic acid is formed, instead of $\left(\mathrm{C}_{2} \mathrm{Cl}_{3}\right)^{\frown} \mathrm{C}_{2},\left\{\begin{array}{l}\mathrm{O}_{2} \\ \mathrm{Cl} \text { : }\end{array}\right.$

$$
\left(\mathrm{C}_{2} \mathrm{Cl}_{3}\right) \text { O. Ac } \mathrm{O}_{3}=2 \mathrm{C}\left\{\begin{array}{l}
\mathrm{O} \\
\mathrm{Cl}
\end{array}+\mathrm{Ac}\left\{\begin{array}{l}
\mathrm{O}_{2} \\
\mathrm{Cl}
\end{array}\right.\right.
$$

The above rationale holds good likewise with respect to the conversion of perchloracetic ether into two equivalents of the dinoxychloride of trichloracetyl (chloraldehyde), having the same composition as the former, by the passage of its vapours through a red-hot tube:

$$
\begin{aligned}
\underbrace{\left(\mathrm{C}_{4} \mathrm{Cl}_{5}\right) \mathrm{O} \cdot\left(\mathrm{C}_{2} \mathrm{Cl}_{3}\right)-\mathrm{C}_{2}, \mathrm{O}_{3}}_{\text {Perchloracetic ether. }}=\underbrace{\left(\mathrm{C}_{2} \mathrm{Cl}_{3}\right)-\mathrm{C}_{2},\left\{\begin{array}{l}
\mathrm{O}_{2} \\
\mathrm{Cl}
\end{array} \cdot\left(\mathrm{C}_{2} \mathrm{Cl}_{3}\right)^{-} \mathrm{C}_{2}, \mathrm{O}_{3}\right.}_{\text {Chloraldehyde. }} & =\underbrace{\left(\mathrm{C}_{2} \mathrm{Cl}_{3}\right)-\mathrm{C}_{2},\left\{\begin{array}{l}
\mathrm{O}_{2} \\
\mathrm{Cl}
\end{array}\right.}_{2}
\end{aligned}
$$

the decomposition of chlorinated formiate of oxide of ethyl into chloraldehyde and chloracarbonic acid :

$$
\begin{aligned}
& \underbrace{\left(\mathrm{C}_{4} \mathrm{Cl}_{5}\right) \mathrm{O} \cdot \mathrm{Cl}^{-} \mathrm{C}_{2}, \mathrm{O}_{3}=\left(\mathrm{C}_{2} \mathrm{Cl}_{3}\right)^{-} \mathrm{C}_{2}}_{\text {Perchloroformic ether. }}, \underbrace{\left\{\begin{array}{l}
\mathrm{O} \\
\mathrm{Cl}_{2}
\end{array}+\mathrm{Cl}^{-} \mathrm{C}_{2}, \mathrm{O}_{3}\right.}_{\text {Chloraldehyde. }} \\
& =\underbrace{\left(\mathrm{C}_{2} \mathrm{Cl}_{3}\right.})^{-} \mathrm{C}_{2},\left\{\begin{array}{l}
\mathrm{O}_{2} \\
\mathrm{Cl}
\end{array}+2 \mathrm{C}\left\{\begin{array}{l}
\mathrm{O} \\
1
\end{array}\right.\right.
\end{aligned}
$$

that of perchloroxalic ether into chloraldehyde, chlorocarbonic acid and carbonic oxide (the two latter being doubtless products of decomposition of $\mathrm{C}_{2}\left\{\begin{array}{l}\mathrm{O}_{2} \\ \mathrm{Cl}\end{array}\right.$ (still unknown) :

$$
\begin{aligned}
& \left(\mathrm{C}_{4} \mathrm{Cl}_{5}\right) \mathrm{O} \cdot \mathrm{C}_{2} \mathrm{O}_{3}=\left(\mathrm{C}_{8} \mathrm{Cl}_{3}\right)^{\wedge} \mathrm{C}_{2},\left\{\begin{array}{l}
\mathrm{O} \\
\mathrm{Cl}_{2}
\end{array}+\mathrm{C}_{2} \mathrm{O}_{3}\right. \\
& \text { Perchloroxalic ether. }
\end{aligned}
$$

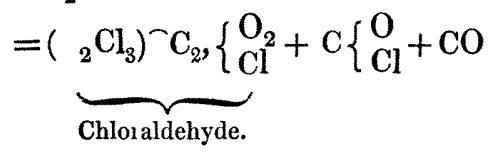

as also with the decomposition of the perchlorinated acetate of oxide of methyl, isomeric with perchloroformic ether, into chlorocarbonic acid and chloraldehyde: 


$$
(\underbrace{\left(\mathrm{C}_{2} \mathrm{Cl}_{3}\right) \mathrm{O} \cdot\left(\mathrm{C}_{2} \mathrm{Cl}_{3}\right)-\mathrm{C}_{2}, \mathrm{O}_{3}=2}_{\text {Chlorinated acetate of oxide of methyl. }}\{\begin{array}{l}
\mathrm{O} \\
\mathrm{Cl}
\end{array}+\underbrace{\left(\mathrm{C}_{2} \mathrm{Cl}_{3}\right)-\mathrm{C}_{2},\left\{\begin{array}{l}
\mathrm{O}_{2} \\
\mathrm{Cl}
\end{array}\right.}_{\text {Chloraldehyde. }}
$$

of chlorinated formiate of oxide of methyl into four equivalents of the isomeric compound, chlorocarbonic acid :

$$
\underbrace{\left(\mathrm{C}_{2} \mathrm{Cl}_{3}\right) \mathrm{O} \cdot \mathrm{Cl}^{-} \mathrm{C}_{2}, \mathrm{O}_{3}=\underbrace{4}_{\begin{array}{c}
\text { Chlorocarbonic } \\
\text { acid. }
\end{array}} \mathrm{C}\left\{\begin{array}{l}
\mathrm{O} \\
\mathrm{Cl}
\end{array}\right.}_{\begin{array}{c}
\text { Chlorinated formiate of } \\
\text { oxide of methyl. }
\end{array}}
$$

and of the chlorinated oxalate of oxide of methyl, into chlorocarbonic acid and carbonic oxide :

$$
\begin{aligned}
& \left(\mathrm{C}_{2} \mathrm{Cl}_{3}\right) \mathrm{O} \cdot \mathrm{C}_{2} \mathrm{O}_{3}=2 \mathrm{C}\left\{\begin{array}{l}
\mathrm{O} \\
\mathrm{Cl}
\end{array}+\mathrm{C}_{2},\left\{\begin{array}{l}
\mathrm{O}_{2} \\
\mathrm{Cl}
\end{array}=3 \mathrm{C}\left\{\begin{array}{l}
\mathrm{O} \\
\mathrm{Cl}
\end{array}+\mathrm{C} \mathrm{O}\right.\right.\right. \\
& \text { Chlorinated oxalate of } \\
& \text { oxide of methyl. }
\end{aligned}
$$

The metamorphosis of perchlorocarbonic ether, by exposure to heat, into chloraldehyde, sesquichloride of carbon, and carbonic acid,

$$
\begin{aligned}
& \underbrace{\left(\mathrm{C}_{4} \mathrm{Cl}_{5}\right) \mathrm{O}}_{\text {Chlorocarbonic ether. }} \cdot \underbrace{\mathrm{CO}_{2}}_{\text {Chloraldehyde. }}=\left(\mathrm{C}_{2} \mathrm{Cl}_{3}\right)-\mathrm{C}_{2},\left\{\begin{array}{l}
\mathrm{O} \\
\mathrm{Cl}_{2}
\end{array}+\mathrm{CO}_{2}=\right. \\
& \qquad \underbrace{\left(\mathrm{C}_{2} \mathrm{Cl}_{3}\right)-\mathrm{C}_{2},\left\{\begin{array}{l}
\mathrm{O}_{2} \\
\mathrm{Cl}
\end{array}\right)}_{\frac{1}{2}}+\mathrm{C}_{2} \mathrm{Cl}_{3}+\mathrm{CO}_{2}
\end{aligned}
$$

exhibits a slight deviation from the above, which is evidently based, partly upon the property of carbonic acid of existing in the anhydrous state, and partly upon its volatility. The latter is probably the principal cause why the carbonic acid, at the moment that it should exchange an equivalent of oxygen for an equivalent of chlorine with the intermediate product, oxydichloride of trichloracetyl $\left(\mathrm{C}_{2} \mathrm{Cl}_{3}\right) \sim \mathrm{C}_{2},\left\{\begin{array}{l}\mathrm{O} \\ \mathrm{Cl}_{2}\end{array}\right.$ (which is undergoing transposition), evades this metamorphosis, so that the latter substance alone undergoes a further change; and thus we obtain, instead of chloraldehyde and chlorocarbonic acid, carbonic acid and the products of decomposition of oxydichloride of trichloracetyl, namely, chloraldehyde and sesquichloride of carbon. 
We find, in accordance with the above assumptions, that perchloracetic ether: $\left(\mathrm{C}_{4} \mathrm{Cl}_{5}\right) \mathrm{O} .\left(\mathrm{C}_{2} \mathrm{Cl}_{3}\right)^{-} \mathrm{C}_{2}, \mathrm{O}_{3}=2\left(\mathrm{C}_{2} \mathrm{Cl}_{3}\right)^{-} \mathrm{C}_{2},\left\{\begin{array}{l}\mathrm{O}_{2} \\ \mathrm{Cl}\end{array}\right)$ behaves with potassa, ammonia, and alcohol, exactly like dinoxychloride of trichloracetyl (chloraldehyde) ; potassa forming with it trichloracetate of potassa and chloride of potassium; ammonia : dinoxamide of trichloracetyl (chloracetamide) and chloride of ammonium; alcohol : trichloracetate of oxide of ethyl and hydrochloric acid.-In like manner, chlorinated formiate of oxide of ethyl and the metameric acetate of oxide of methyl, behave with these reagents like a mixture of chlorocarbonic acid and chloraldehyde (compare their metamorphoses at a high temperature, p. 399). Solution of potassa converts them nto trichloracetate and carbonate of potassa, and chloride of potassium ; ammonia into chloracetamide and chloride of ammonium (and doubtless into carbamide or its products of decomposition); alcohol into trichloracetate and oxychlorocarbonate of oxide of ethyl and hydrochloric acid; methyl-alcohol into the corresponding methylethers.-Chlorinated carbonate of oxide of ethyl, which is converted by potassa into chloride of potassium, carbonate and formiate of potassa (the latter being evidently a product of decomposition of the previously formed trichloracetate of potassa) ; by ammonia into chloride of ammonium, chloracetamide (and probably carbamide and carbamate of ammonia), and which furnishes, with alcohol, trichloracetate and carbonate of oxide of ethyl, besides hydrochloric acid, resembles in these metamorphoses an instable compound of chloraldehyde and chlorocarbonic acid: $\left(\mathrm{C}_{4} \mathrm{Cl}_{5}\right)$ O $. \mathrm{CO}_{2}=\left(\mathrm{C}_{2} \mathrm{Cl}_{3}\right)^{-} \mathrm{C}_{2},\left\{\begin{array}{l}\mathrm{O}_{2} \\ \mathrm{Cl}\end{array}\right.$ or a compound of oxydichloride of trichloracetyl with carbonic acid: $\left(\mathrm{C}_{4} \mathrm{Cl}_{5}\right) \mathrm{O}, \mathrm{CO}_{2}=\left(\mathrm{C}_{2} \mathrm{Cl}_{3}\right)^{-} \mathrm{C}_{2},\left\{\begin{array}{l}\mathrm{O} \\ \mathrm{Cl}_{2}\end{array} . \mathrm{CO}_{2}\right.$, if we may assume that oxydichloride of trichloracetyl, at the moment of its formation, can pass over, with the elements of water, into trichloracetylic and hydrochloric acids, analogously to the dinoxychloride of trichloracetyl.-The chlorinated oxalate of oxide of ethyl, which yields with potassa: trichloracetate and oxalate of potassa and chloride of potassium; with ammonia: chloracetamide, chloride of ammonium, and probably oxamide; with alcohol : trichloracetate and oxalate of oxide of ethyl, together with hydrochloric acid and chloride of ethyl, comports itself like a compound of chloraldehyde with a hypothetical oxalo-dinoxychloride, corresponding to oxamide: $\mathrm{C}_{2},\left\{\begin{array}{l}\mathrm{O}_{2} \\ \mathrm{Cl}\end{array}\right.$ which may be presumed to be decomposed by ammonia into chloride of ammonium and oxamide. In the decompo- 
sition of chlorinated oxalate of oxide of ethyl by alcohol, Malaguti obscrved, besides the formation of oxalic ether and chloracetic ether, the production of the body $\mathrm{C}_{8} \mathrm{Cl}_{5} \mathrm{O}_{7}$ (Chloroxethide $\mathrm{M}$ ), corresponding in composition to the formula $\left(\mathrm{C}_{4} \mathrm{Cl}_{5}\right)$ O.2 $\mathrm{C}_{2} \mathrm{O}_{3}$ (?).

In the same manner, the decomposition of chlorinated oxalate of methyl by potassa into chloride of potassium, oxalate and carbonate of potassa,-by alcohol into hydrochloric acid, oxalate and chlorocarbonate of oxide of ethyl,- - and by ammonia into chloride of ammonia and carbamide (and doubtless oxamide) corresponds perfectly with the comportment of a compound of chlorocarbonic acid with the above-mentioned hypothetical oxalo-dinoxychloride.

It might be expected, from the analogy of chlorinated formiate of oxide of ethyl with the other compound chlorinated ethers, that it would comport itself with the above reagents, like chlorocarbonic acid, into which it is converted by the action of a high temperature : $\left(\mathrm{C}_{2} \mathrm{Cl}_{3}\right)$ O. $\mathrm{Cl}^{-} \mathrm{C}_{2}, \mathrm{O}_{3}=4 \mathrm{C}\left\{\begin{array}{l}\mathrm{O} \\ \mathrm{Cl}^{\circ}\end{array}\right.$. The formation of oxychlocarbonate of oxide of ethyl and hydrochloric acid by treatment of the chlorinated ether with alcohol, is likewise in accordance with this supposition; instead, however, of yielding chloride of ammonium and carbamide, by treatment with ammonia, it is stated by Cahours to yield dinoxamide of trichloracetyl (chloracetamide).

AIthough the percentage-composition obtained by Cahours for the latter compound agrees exactly with that of chloracetamide, I cannot refrain from doubting the above statement, and presuming that it must be based upon some error. Additional weight is given to this supposition by the fact that, in endeavouring to construct the formula of chloracetamide from that of the chlorinated formiate of oxide of methyl, there remain two atoms of oxygen, of the use of which no account can be rendered, as will be seen from the following equation :

$$
\underbrace{\left(\mathrm{C}_{2} \mathrm{Cl}_{3}\right) \text { O. } \mathrm{Cl}^{-} \mathrm{C}_{2}, \mathrm{O}_{3}}_{\text {Chlorinated formiate of }}+2 \mathrm{NH}_{3}=\underbrace{\left(\mathrm{C}_{2} \mathrm{Cl}_{3}\right)-\mathrm{C}_{2},\left\{\begin{array}{l}
\mathrm{O}_{2} \\
\mathrm{NH}_{2}
\end{array}\right.}_{\text {Chloracetamide. }}+\mathrm{N} \mathrm{H}_{4} \mathrm{Cl}+2 \mathrm{O}
$$
oxide of methyl.

It is very desirable that Cahours should repeat this experiment, and remove the doubts on the subject.

I shall refrain from making any observations on chlorosuccinic ether and its complicated decompositions, described by Malaguti, as it is my belief that the metamorphoses which free succinic acid undergoes by the action of chlorine, must be first examined and determined, 
before we can furnish any account of the rational composition of chlorosuccinic ether, or of its products of decomposition.

The perfect similarity exhibited by chlorinated acetate of oxide of methyl and chlorinated formate of oxide of ethyl, as far as our present knowledge of them extends, has induced most chemists to consider them as identical. While the most different views exist respecting the manner in which the elements are grouped in these two compounds, their supposed identity has been employed as an argument against the assertion, that compound clorinated ethers still possess the constitution of the normal ethers. I myself am far from concluding that, because the chlorinated ethers, which have hitherto been more carefully examined, exhibit an analogy with those from which they have been produced,-the molecular arrangement of the atoms and of the proximate constituents must likewise remain unaltered in the action of chlorine on all other compound ethers; on the contrary, I consider it more than probable that ethers of complex composition, such as chlorinated amylic-ether, valerianic, or even margaric ethers, cease to possess the constitution of the original ethers long before the whole of the hydrogen is replaced by chlorine. Perhaps even the chlorinated succinic ether belongs to this class, as its complex composition and metamorphoses lead to the assumption that the exchange of its hydrogen for chlorine is followed by a far more intricate decomposition. The identity of chlorinated formiate of oxide of ethyl and chlorinated acetate of oxide of methyl, even if it were established, could therefore not serve absolutely to determine our views concerning the nature of other chlorinated ethers. But I am not of opinion that the two latter compounds have the saine chemical constitution, and are really identical, because they are alike in their comportment. If we view these two others as composed according to the rational formulæ:

$\left(\mathrm{C}_{4} \mathrm{Cl}_{5}\right) \mathrm{O} \cdot \mathrm{Cl}^{-} \mathrm{C}_{2}, \mathrm{O}_{3}$ chlorinated formiate of oxide of ethyl, $\left(\mathrm{C}_{2} \mathrm{Cl}_{3}\right) \mathrm{O} \cdot\left(\mathrm{C}_{2} \mathrm{Cl}_{3}\right)-\mathrm{C}_{2}, \mathrm{O}_{3}$ chlorinated acetate of oxide of methyl,

and consider, at the same time, that their proximate constituents$\left(\mathrm{C}_{4} \mathrm{Cl}_{5}\right) \mathrm{O}$ and $\mathrm{Cl}^{-} \mathrm{C}_{2}, \mathrm{O}_{3}$ on the one hand, $\left(\mathrm{C}_{2} \mathrm{Cl}_{3}\right) \mathrm{O}$, and $\left(\mathrm{C}_{2} \mathrm{Cl}_{3}\right)^{-} \mathrm{C}_{2} \mathrm{O}_{3}$ on the other-are held together with but feeble affinity-if we bear in mind, moreover, that, as no one of these adjuncts exists in the uncombined state, at the moment that their chemical equilibrium is disturbed by the influence of any agent, their further decomposition must be preceded by a transposition of their atoms after the following manner:

$$
\underbrace{\left(\mathrm{C}_{4} \mathrm{Cl}_{5}\right) \mathrm{O}}_{\begin{array}{c}
\text { Chlorinated formiate of oxide } \\
\text { of ethyl. }
\end{array}} \cdot \underbrace{\mathrm{Cl}^{-\mathrm{C}_{2}}, \mathrm{O}_{3}}_{\text {Chloraldehyde. }}=\underbrace{\left(\mathrm{C}_{2} \mathrm{Cl}_{3}\right) \mathrm{C}_{2},\left\{\begin{array}{l}
\mathrm{O}_{2} \\
\mathrm{Cl}
\end{array}+2 \mathrm{C}\left\{\begin{array}{l}
\mathrm{O} \\
\mathrm{Cl}
\end{array}\right.\right.}_{\begin{array}{c}
\text { Chlorocarbon } \\
\text { acid. }
\end{array}}
$$




$$
\underbrace{\left(\mathrm{C}_{2} \mathrm{Cl}_{3}\right) \mathrm{O} \cdot\left(\mathrm{C}_{2} \mathrm{Cl}_{3}\right) \mathrm{C}_{2}, \mathrm{O}_{3}}_{\text {Chlorinated acetate of oxide of methyl. }}=\underbrace{\left(\mathrm{C}_{2} \mathrm{Cl}_{3}{ }^{\mathrm{C}_{2}},\left\{\begin{array}{l}
\mathrm{O}_{2} \\
\mathrm{Cl}
\end{array}\right.\right.}_{\text {Chloraldehyde. }}+\underbrace{2 \mathrm{C}\left\{\begin{array}{l}
\mathrm{O} \\
\mathrm{Cl}
\end{array}\right.}_{\text {Chlorocarbonic acid. }}
$$

(these metamorphoses being produced in reality by the action of a high temperature);-if all these circumstances be duly considered, it will be easily understood why these two bodies exhibit a similar comportment, or, at any rate, yield the same products of decomposition with such agents as are capable of effecting this disturbance in the chemical equilibrium of their constituents. Their correspondence, besides, in specific gravity, boiling-point, \&c., must, least of all, excite surprise, as even the two normal ethers, from which they are produced, exhibit a perfect similarity in these respects. Acetate of oxide of methyl and formiate of oxide of ethyl are well known to differ only in their behaviour when boiled with alkalis; they evidently owe this mark of distinction to the greater stability of their constituents, without which they would probably be likewise considered as identical. I feel convinced that, by a careful investigation and comparison of these two chlorinated ethers, for instance, with regard to their refractive power, or to their behaviour with such bodies as do not effect their decomposition, their relative solubilities in ether, benzol, and so on, some slight varieties will be discovered between them, which will lead to a proof of their dissimilarity by experimental means.

If the compound ethers, which have been the subject of our consideration, in which all the hydrogen is replaced by chlorine, still possess the constitution of the original substances, it follows necessarily that the molecular arrangement of the atoms in the intermediate products must likewise be the same. The dichlorinated acetic ether, which is decomposed by water and potassa into acetic and hydrochloric acids, corresponds, therefore, in composition to the formula: $\left(\mathrm{C}_{4}\left\{\begin{array}{l}\mathrm{H}_{3} \\ \mathrm{Cl}_{2}\end{array}\right)\right.$ O. $\left(\mathrm{C}_{2} \mathrm{H}_{3}\right)^{-} \mathrm{C}_{2}, \mathrm{O}_{3}$. Its conversion into these products is probably preceded, as with perchloracetic ether, by a separation of the two members, and as $\left(\mathrm{C}_{4}\left(\begin{array}{l}\mathrm{H}_{3} \\ \mathrm{Cl}_{2}\end{array}\right) \mathrm{O}\right.$ cannot exist in the free state, by a transposition of these atoms to $\left(\mathrm{C}_{2} \mathrm{H}_{3}\right)-\mathrm{C}_{2},\left\{\begin{array}{l}\mathrm{O} \\ \mathrm{Cl}^{2}\end{array}\right.$ (oxydichloride of acetyl). The trichlorinated acetate of oxide of ethyl, produced by a continuation of the process of substitution, is either acetate of oxide of trichlorethyl $\left(\mathrm{C}_{2}\left\{\begin{array}{l}\mathrm{H}_{2} \\ \mathrm{Cl}_{2}\end{array}\right)\right.$ O. $\left(\mathrm{C}_{2} \mathrm{H}_{3}\right)^{-} \mathrm{C}_{2}, \mathrm{O}_{3}$, or D D 2 
monochloracetate of oxide of dichlorethyl

$$
\left(\mathrm { C } _ { 4 } \{ \begin{array} { l } 
{ \mathrm { H } _ { 3 } } \\
{ \mathrm { Cl } _ { 2 } }
\end{array} ) \text { O. } \left(\mathrm{C}_{2}\left\{\begin{array}{l}
\mathrm{H}_{2} \\
\mathrm{Cl}
\end{array}\right)^{-} \mathrm{C}_{2}, \mathrm{O}_{3}\right.\right. \text {. }
$$

The deliquescent potassa-salt-containing chlorine, obtained therefrom according to Leblanc, by treatment with solution of potassa, is probably monochloracetate of potassa mixed with acetate of potassa; and the oily body simultaneously deposited, is possibly a secondary product of decomposition, produced from monochloracetic acid, in a manner similar to the formation of trichloride of formyl from trichloracetic acid.

By the distillation of trichloracetic acid with alcohol containing sulphuric acid, as also by the treatment of dinoxychloride of trichloracetyl with alcohol, an ether isomeric with the above compound is produced, namely, trichloracetate of oxide of ethyl, differing greatly in its behaviour from the former, and particularly in the circumstance that it yields alcohol again, by treatment with boiling potassa. A comparison of their rational formulæ will suffice to account for their isomerism :

$\left(\mathrm{C}_{4}\left\{\begin{array}{l}\mathrm{H}_{3} \\ \mathrm{Cl}_{2}\end{array}\right)\right.$ O. $\left(\mathrm{C}_{2}\left\{\begin{array}{l}\mathrm{H}_{2} \\ \mathrm{Cl}^{2}\end{array}\right)^{-} \mathrm{C}_{2}, \mathrm{O}_{3}\right.$ trichlorinated acetic ether.

$\left(\begin{array}{ll}\mathrm{C}_{4} & \mathrm{H}_{5}\end{array}\right)$ O. $\left(\mathrm{C}_{2} \quad \mathrm{Cl}_{3}\right)^{\frown} \mathrm{C}_{2}, \mathrm{O}_{3}$ trichloracetic ether.

Among the intermediate substitution-products of compound ethers, in which only a portion of the hydrogen is replaced by chlorine, and which have, generally speaking, been less carefully studied, the dichlorinated acetate of oxide of methyl, and the dichlorinated formiate of oxide of ethyl are particularly distinguished, not merely by being isomeric, like the final products above-mentioned, but also by corresponding in their chemical comportment, without, however, being identical. If they be considered as composed according to the rational formulæ :

$\left(\mathrm{C}_{2}\left\{\begin{array}{l}\mathrm{H} \\ \mathrm{Cl}_{2}\end{array}\right) \mathrm{O} \cdot\left(\mathrm{C}_{2} \mathrm{H}_{3}\right)^{-} \mathrm{C}_{2}, \mathrm{O}_{3}\right.$ dichlorinated acetate of oxide of methyl $\left(\mathrm{C}_{4}\left\{\begin{array}{l}\mathrm{H}_{3} \\ \mathrm{Cl}_{2}\end{array}\right) \mathrm{O} . \quad \mathrm{H}^{-} \mathrm{C}_{2}, \mathrm{O}_{3}\right.$ dichlorinated formiate of oxide of ethyl, the decomposition of both by potassa into acetic, formic and hydrochloric acids, admits of a ready explanation. In the first compound, the decomposition is probably preceded by the transposition of $\left(\mathrm{C}_{2}\left\{\begin{array}{l}\mathrm{H} \\ \mathrm{Cl}_{2}\end{array}\right) \mathrm{O}\right.$ into $\mathrm{H}^{-} \mathrm{C}_{2},\left\{\begin{array}{l}\mathrm{O} \\ \mathrm{Cl}_{2}\end{array}\right.$ (oxydichloride of formyl), and, in the second case, by the metamorphosis of $\left(\mathrm{C}_{4}\left\{\begin{array}{l}\mathrm{H}_{3} \\ \mathrm{Cl}_{2}\end{array}\right) \mathrm{O}\right.$ into $\left(\mathrm{C}_{2} \mathrm{H}_{3}\right)^{-} \mathrm{C}_{2},\left\{\begin{array}{l}\mathrm{O} \\ \mathrm{Cl}_{2}\end{array}\right.$ (oxydichloride of acetyl). The formic acid is therefore produced, in the first case, from the basic member, and in the second case, from the acid member of the dichlorinated ethers ; on the other hand, the 
MR. BRODIE ON THE ALCOHOL RADICALS.

acetic acid produced in this reaction from the dichlorinated formiate of oxide of ethyl, must be considered as a product of decomposition of the member $\left(\mathrm{C}_{4}\left\{\begin{array}{l}\mathrm{H}_{3} \\ \mathrm{Cl}_{2}\end{array}\right) \mathrm{O}\right.$, while it is pre-existing as such in the dichlorinated acetate of oxide of methyl.

(To be concluded in the next Journal.) 